\title{
Cytotoxic Withanolide Constituents of Physalis longifolia
}

\author{
Huaping Zhang, ${ }^{\dagger}$ Abbas K. Samadi, ${ }^{\dagger}$ Robert J. Gallagher, ${ }^{\dagger}$ Juan J. Araya, ${ }^{\dagger}$ Xiaoqin Tong, ${ }^{\dagger}$ Victor W. Day, ${ }^{\S}$
} Mark S. Cohen, ${ }^{\dagger}$ Kelly Kindscher, ${ }^{\perp}$ Rao Gollapudi, ${ }^{\dagger}$ and Barbara N. Timmermann ${ }^{*}{ }^{\dagger}$

${ }^{\dagger}$ Department of Medicinal Chemistry, School of Pharmacy, University of Kansas, Lawrence, Kansas 66045, United States

${ }^{\ddagger}$ Department of Surgery, School of Medicine, University of Kansas, Medical Center, Kansas City, Kansas 66160, United States

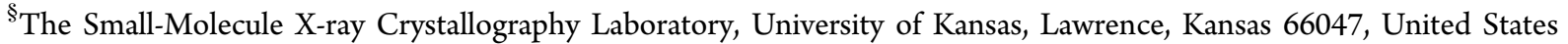

${ }^{\perp}$ Kansas Biological Survey, University of Kansas, Lawrence, Kansas 66047, United States

Supporting Information

ABSTRACT: Fourteen new withanolides, 1-14, named withalongolides $\mathrm{A}-\mathrm{N}$, respectively, were isolated from the aerial parts of Physalis longifolia together with eight known compounds (15-22). The structures of compounds 1-14 were elucidated through spectroscopic techniques and chemical methods. In addition, the structures of withanolides $1,2,3$, and 6 were confirmed by X-ray crystallographic
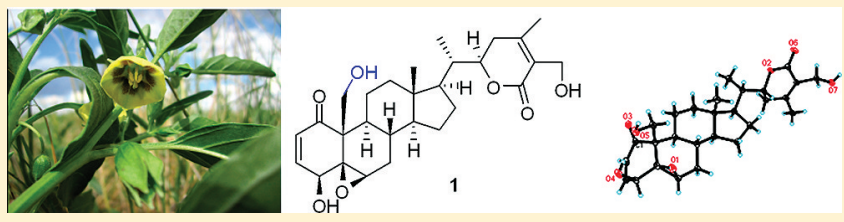
analysis. Using a MTS viability assay, eight withanolides $(1,2,3,7,8,15,16$, and 19) and four acetylated derivatives (1a, 1b, 2a, and $\mathbf{2 b}$ ) showed potent cytotoxicity against human head and neck squamous cell carcinoma (JMAR and MDA-1986), melanoma (B16F10 and SKMEL-28), and normal fetal fibroblast (MRC-5) cells with $\mathrm{IC}_{50}$ values in the range between 0.067 and $9.3 \mu \mathrm{M}$.

$\mathrm{C}$ lassically defined withanolides are a group of $\mathrm{C}_{28}$ ergostane-type steroids with a C-22,26 $\delta$-lactone group, first isolated from the genus Withania. ${ }^{1}$ They are present primarily in the Solanaceae family, which includes the genera Acnistus, Datura, Dunalia, Jaborosa, Nicandra, Physalis, and Withania. $^{2-9}$ Withanolides have attracted interest in recent years mainly due to their exhibition of significant biological activities, inclusive of antimicrobial, antitumor, anti-inflammatory, immunomodulatory, and insect-antifeedant activities. ${ }^{2,3,6}$ It has been reported that those withanolides displaying the most promising antitumor characteristics contain an $\alpha, \beta$ unsaturated ketone in ring $\mathrm{A}$, a $5 \beta, 6 \beta$-epoxy group in ring $\mathrm{B}$, and a nine-carbon side chain with an $\alpha, \beta$-unsaturated $\delta$-lactone group. ${ }^{10}$ The typical withanolide withaferin A (16) (Figure 1) contains these three moieties and has been shown in vitro and in vivo to suppress the growth of an array of tumor cells, including breast, pancreatic, prostate, lung, leukemia, and head and neck squamous cell carcinoma (HNSCC), by inducing apoptosis, $^{11}$ thus possessing potential application as an antiproliferative agent. As part of an ongoing study of withanolides from plant sources, ${ }^{11,12}$ a library of 224 native plant extracts from the U.S. Great Plains was evaluated for cytotoxic activities against HNSCC and melanoma cell lines using the MTS viability assay. One of the most promising leads, Physalis longifolia Nutt. (Solanaceae), commonly known as "long leaf groundcherry", was subjected to a phytochemical investigation, and the results are presented herein, including the details of the isolation and structure elucidation of 14 new withanolides (1-14), four acetylated derivatives (1a, 1b, 2a, and 2b), and eight known compounds (15-22). Their cytotoxicity was determined against HNSCC (JMAR and MDA-1986), melanoma (B16F10 and SKMEL-28), and normal fetal fibroblast (MRC-5) cells. This constitutes the first report of a phytochemical and bioactivity study of $P$. longifolia.

\section{RESULTS AND DISCUSSION}

The $\mathrm{CH}_{2} \mathrm{Cl}_{2}-\mathrm{MeOH}(1: 1)$ extract of the aerial parts of the title plant and the EtOAc-soluble and $n$-BuOH-soluble fractions showed cytotoxicity against the above-mentioned cells with $\mathrm{IC}_{50}$ values in the range between 0.7 and $9.8 \mu \mathrm{g} / \mathrm{mL}$ using a MTS assay. All compounds (1-22) were isolated from the EtOAc-soluble or $n$-BuOH-soluble fractions (see Experimental Section).

Compound 1 was isolated as colorless cuboid crystals obtained from a $\mathrm{CH}_{2} \mathrm{Cl}_{2}-\mathrm{CH}_{3} \mathrm{CN}$ mixture, a major metabolite in the EtOAc-soluble fraction. Its molecular formula, $\mathrm{C}_{28} \mathrm{H}_{38} \mathrm{O}_{7}$, was determined by HRESIMS and NMR experiments, equating to 10 double-bond equivalents. Its IR absorptions revealed the presence of hydroxy (3431 and $\left.3233 \mathrm{~cm}^{-1}\right)$, keto $\left(1671 \mathrm{~cm}^{-1}\right)$, and ester $\left(1706 \mathrm{~cm}^{-1}\right)$ groups. The ${ }^{1} \mathrm{H}$ NMR spectrum (Table 1) showed the presence of three methyl groups at $\delta 0.60(3 \mathrm{H}, \mathrm{s})$, $0.90(3 \mathrm{H}, \mathrm{d}, J=6.6 \mathrm{~Hz})$, and $1.97(3 \mathrm{H}, \mathrm{s})$, seven protons attached to oxygenated carbons at $\delta 3.18(1 \mathrm{H}, \mathrm{brs}), 3.52(1 \mathrm{H}$, d, $J=6.1 \mathrm{~Hz}), 3.65(1 \mathrm{H}, \mathrm{d}, J=9.6 \mathrm{~Hz}), 4.17(1 \mathrm{H}, \mathrm{d}, J=9.6$ $\mathrm{Hz}), 4.23(1 \mathrm{H}, \mathrm{d}, J=12.5 \mathrm{~Hz}), 4.28(1 \mathrm{H}, \mathrm{d}, J=12.5 \mathrm{~Hz})$, and $4.33(1 \mathrm{H}, \mathrm{dt}, J=13.3,3.4 \mathrm{~Hz})$, and two olefinic methine groups at $\delta 6.16(1 \mathrm{H}, \mathrm{d}, J=10.0 \mathrm{~Hz})$ and $6.95(1 \mathrm{H}, \mathrm{dd}, J=10.0,6.1$ $\mathrm{Hz}$ ). The ${ }^{13} \mathrm{C}$ NMR (APT) and HSQC spectra for 1 (Table 2) displayed 28 carbon signals differentiated as three $\mathrm{CH}_{3}$, eight $\mathrm{CH}_{2}$ (including two oxygenated at $\delta 61.0$ and 56.7), $10 \mathrm{CH}$ (including two olefins at $\delta 145.7$ and 132.9, three oxygenated at

Received: August 11, 2011

Published: November 18, 2011 


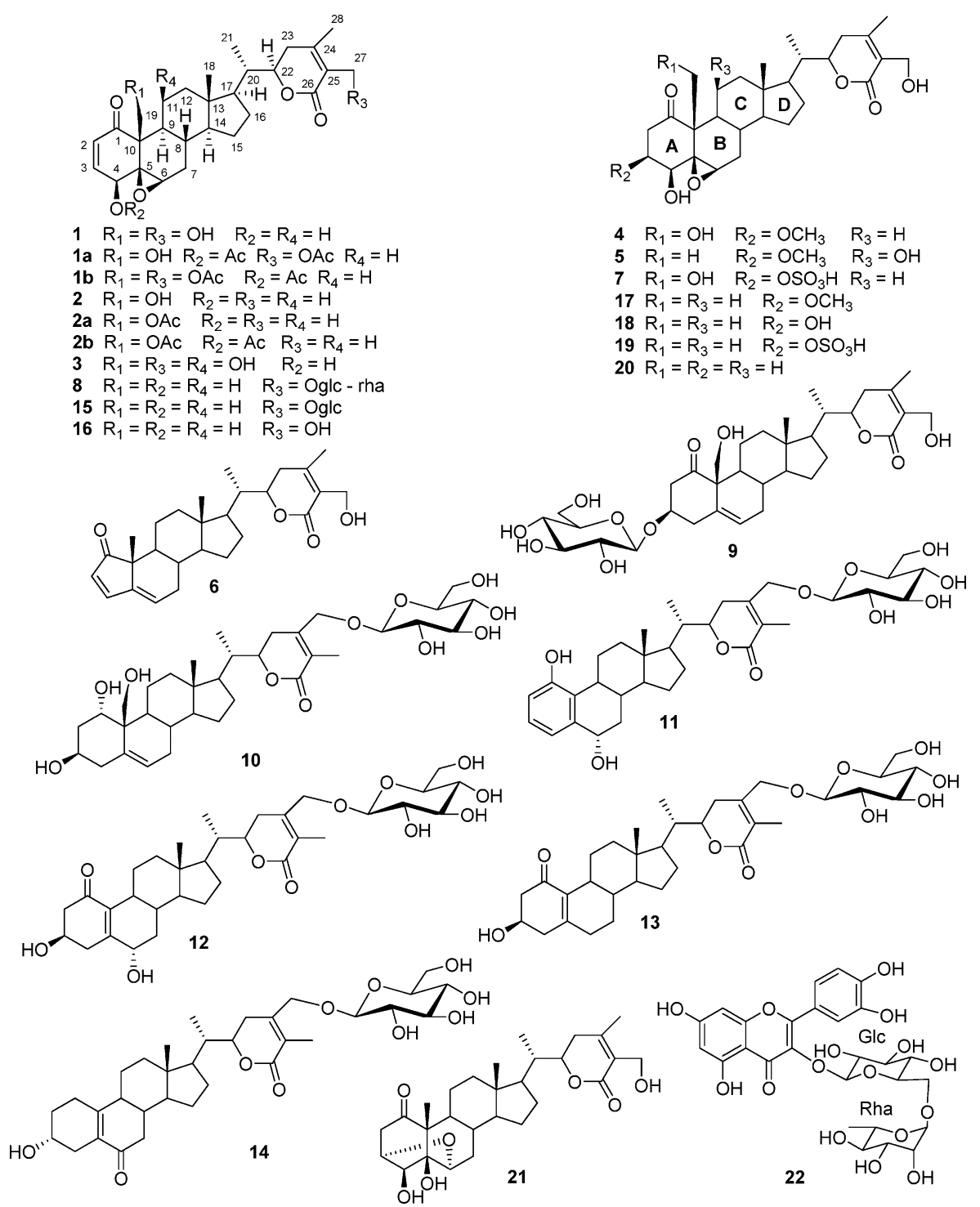

Figure 1. Withanolides 1-21 and rutin (22) isolated from Physalis longifolia.

$\delta$ 78.8, 68.0, and 61.8), and seven C (including one keto carbonyl at $\delta 200.7$, one ester carbonyl at $\delta 167.4$, two olefins at $\delta 154.3$ and 125.6 , and one oxygenated at $\delta 61.5$ ), corresponding to $\mathrm{C}_{28} \mathrm{H}_{35}$. The remaining three hydrogen atoms were therefore assigned to three $\mathrm{OH}$ groups, indicating that six rings must be present in the structure.

The NMR data of 1 were very close to those obtained for withaferin A 16, ${ }^{1,13}$ a six-ring withanolide isolated as another major compound in this study (Tables $1-3$ and Figure 1). Compound 1 was found to contain the following moieties also observed in 16: an $\alpha, \beta$-unsaturated ketone in ring $\mathrm{A}\left(\left[{ }^{13} \mathrm{C}: \delta\right.\right.$ 200.7 (C-1), 132.9 (C-2), 145.7 (C-3); ${ }^{1} \mathrm{H}: \delta 6.16$ (H-2, d, $J=$ $10.0 \mathrm{~Hz}), 6.95(\mathrm{H}-3$, dd $J=10.0,6.1 \mathrm{~Hz})]$; an epoxy group in ring $\mathrm{B}\left[{ }^{13} \mathrm{C}: \delta 61.5(\mathrm{C}-5), 61.8(\mathrm{C}-6) ;{ }^{1} \mathrm{H}: \delta 3.18\right.$ (brs, $\left.\left.\mathrm{H}-6\right)\right]$; and a nine-carbon side chain with an $\alpha, \beta$-unsaturated $\delta$-lactone group $\left[{ }^{13} \mathrm{C}: \delta 78.8\right.$ (C-22), $154.3(\mathrm{C}-24), 125.6(\mathrm{C}-25), 167.4$ $\left.\left.(\mathrm{C}-26) ;{ }^{1} \mathrm{H}: \delta 4.33(\mathrm{H}-22, \mathrm{dt}, J=13.3,3.4 \mathrm{~Hz})\right]\right)$, as supported by ${ }^{1} \mathrm{H}-{ }^{1} \mathrm{H}$ COSY and $\mathrm{HMBC}$ experiments. The obvious differences between 1 and 16 were the presence of an oxygenated methylene $\left[\mathrm{C}-19,{ }^{13} \mathrm{C}: \delta 61.0 ;{ }^{1} \mathrm{H}: \delta 3.65(1 \mathrm{H}, \mathrm{d}\right.$, $J=9.6 \mathrm{~Hz}), 4.17(1 \mathrm{H}, \mathrm{d}, J=9.6 \mathrm{~Hz})]$ in 1 and a methyl carbon $\left[\mathrm{C}-19,{ }^{13} \mathrm{C}: \delta 17.6 ;{ }^{1} \mathrm{H}\right.$ : $\left.1.38(3 \mathrm{H}, \mathrm{s})\right]$ in the latter, suggesting that $\mathbf{1}$ is a 19 -hydroxy derivative of $\mathbf{1 6}$. This observation was supported by the high-frequency shift of C-10 $(\delta 54.3$ in 1 and $\delta 47.9$ in 16), the low-frequency shifts of C-1 ( $\delta 200.7$ in 1 and $\delta 202.5$ in 16), C-5 ( $\delta 61.5$ in 1 and $\delta 64.1$ in 16), and C-9 $(\delta$ 43.9 in 1 and $\delta 44.3$ in 16) in the ${ }^{13} \mathrm{C}$ NMR spectra, and the HMBC correlations between $\mathrm{H}_{2}-19$ [3.65 $(1 \mathrm{H}, \mathrm{d}, J=9.6 \mathrm{~Hz})$, $4.17(1 \mathrm{H}, \mathrm{d}, J=9.6 \mathrm{~Hz}]$ and C-1, C-5, C-9, and C-10.

Acetylation of 1 with acetic anhydride in pyridine gave two derivatives, the 4,19,27-triacetate (1a) and the 4,27-diacetate (1b) (Tables 1 and 2), which proved the presence of hydroxy groups at C-4, C-19, and C-27 by a high-frequency shift of $\mathrm{H}-4$ (from $\delta 3.52$ in $\mathbf{1}$ to $\delta 4.79$ in $\mathbf{1 a}$ and to $\delta 4.73$ in $\mathbf{1 b}$ ), of $\mathrm{H}_{2}-19$ (from $\delta 3.65,4.17$ in 1 to $\delta 4.32,5.07$ in 1a), and of $\mathrm{H}_{2}-27$ ( $\delta$ 4.23, 4.28 in 1 to $\delta 4.84,4.88$ in $1 \mathrm{a}$ and to $\delta 4.85,4.88$ in $\mathbf{1 b}$ ) and by HMBC correlations between $\mathrm{H}-4$ and the ester carbonyl, between $\mathrm{H}_{2}-27$ and the ester carbonyl, and between $\mathrm{H}_{2}-19$ and the ester carbonyl in $\mathbf{1 a}$ and $\mathbf{1 b}$.

Finally, the structure of $\mathbf{1}$ was confirmed through a singlecrystal X-ray diffraction experiment (Figure 2). Thus, 1 (withalongolide A) was established as 19-hydroxywithaferin A. The full assignments of NMR data of 1 , measured in $\mathrm{CDCl}_{3}$ with a trace amount of $\mathrm{CD}_{3} \mathrm{OD}$ and in $\mathrm{C}_{5} \mathrm{D}_{5} \mathrm{~N}$ (Tables 1 
Table 1. ${ }^{1} \mathrm{H}$ NMR Data for Withanolides $1,1 \mathrm{a}, 1 \mathrm{~b}, 2,2 \mathrm{a}, 2 \mathrm{~b}$, and 3 (400 or $500 \mathrm{MHz}$ )

\begin{tabular}{|c|c|c|c|c|c|c|c|c|}
\hline pos. & $1^{a}$ & $1^{b}$ & $1 a^{c}$ & $1 b^{c}$ & $2^{c}$ & $2 a^{c}$ & $2 \mathbf{b}^{c}$ & $3^{c}$ \\
\hline 2 & $6.16 \mathrm{~d}(10.0)$ & $6.46 \mathrm{~d}(10.0)$ & $6.23 \mathrm{~d}(10.0)$ & $6.21 \mathrm{~d}(10.0)$ & $6.23 \mathrm{~d}(10.4)$ & $6.23 \mathrm{~d}(9.9)$ & $6.23 \mathrm{~d}(9.9)$ & $6.22 \mathrm{~d}(10.0)$ \\
\hline 3 & $\begin{array}{l}6.95 \text { dd (10.0, } \\
6.1)\end{array}$ & $\begin{array}{l}7.26 \mathrm{dd}(10.0 \\
6.1)\end{array}$ & $\begin{array}{l}7.00 \mathrm{dd}(10.0, \\
6.1)\end{array}$ & $\begin{array}{l}7.00 \mathrm{dd}(10.0 \\
6.1)\end{array}$ & $\begin{array}{l}7.01 \text { dd (10.4, } \\
6.4)\end{array}$ & $7.00 \mathrm{dd}(9.9,6.0)$ & $\begin{array}{l}7.01 \text { dd }(9.9 \\
6.0)\end{array}$ & $6.96 \mathrm{dd}(10.0,6.5)$ \\
\hline 4 & $3.52 \mathrm{~d}(6.1)$ & $4.01 \mathrm{~d}(6.1)$ & $4.79 \mathrm{~d}(6.1)$ & $4.73 \mathrm{~d}(6.1)$ & $3.63 \mathrm{~d}(6.4)$ & $4.79 \mathrm{~d}(6.0)$ & $4.74 \mathrm{~d}(6.0)$ & $3.78 \mathrm{~d}(6.5)$ \\
\hline 6 & $3.18 \mathrm{brs}$ & 3.42 brs & 3.12 brs & $3.20 \mathrm{brs}$ & $3.25 \mathrm{brs}$ & 3.16 brs & $3.20 \mathrm{brs}$ & $3.23 \mathrm{brs}$ \\
\hline \multirow[t]{2}{*}{7} & $2.14 \mathrm{~m}, 1.25 \mathrm{~m}$ & $\begin{array}{l}2.15 \text { ddd }(2.2, \\
4.0,14.5)\end{array}$ & $2.15 \mathrm{~m}$ & $2.01 \mathrm{~m}, 1.96 \mathrm{~m}$ & $\begin{array}{l}2.19 \text { ddd }(2.2 \\
4.2,15.0)\end{array}$ & $2.15 \mathrm{~m}$ & $2.17 \mathrm{~m}$ & $\begin{array}{l}2.26 \text { ddd }(2.4,4.7 \text {, } \\
15.1)\end{array}$ \\
\hline & & $\begin{array}{l}1.37 \text { dd (11.1, } \\
14.5)\end{array}$ & $1.25 \mathrm{~m}$ & & $1.30 \mathrm{~m}$ & $\begin{array}{l}1.25 \text { ddd (1.4, } \\
11.3,15.0)\end{array}$ & $1.28 \mathrm{~m}$ & $1.29 \mathrm{~m}$ \\
\hline 8 & $1.44 \mathrm{~m}$ & $\begin{array}{l}1.64 \mathrm{dq}(4.0, \\
11.1)\end{array}$ & $\begin{array}{l}1.77 \mathrm{dq}(4.2, \\
11.1)\end{array}$ & $1.85 \mathrm{~m}$ & $\begin{array}{l}1.51 \mathrm{dq}(4.2, \\
11.1)\end{array}$ & $1.76 \mathrm{dq}(4.2,11.3)$ & $1.85 \mathrm{~m}$ & $1.87 \mathrm{dq}(4.5,10.8)$ \\
\hline 9 & $0.85 \mathrm{~m}$ & $1.15 \mathrm{~m}$ & $1.00 \mathrm{~m}$ & $0.91 \mathrm{~m}$ & $0.94 \mathrm{~m}$ & $1.00 \mathrm{~m}$ & $0.92 \mathrm{~m}$ & $1.25 \mathrm{dd}(3.3,10.8)$ \\
\hline 11 & $1.90 \mathrm{~m}, 1.32 \mathrm{~m}$ & $2.31 \mathrm{~m}, 1.55 \mathrm{~m}$ & $1.96 \mathrm{~m}, 1.62 \mathrm{~m}$ & $1.94 \mathrm{~m}, 1.85 \mathrm{~m}$ & $1.94 \mathrm{~m}, 1.39 \mathrm{~m}$ & $1.96 \mathrm{~m}, 1.62 \mathrm{~m}$ & $1.94 \mathrm{~m}, 1.84 \mathrm{~m}$ & 4.15 (brs) \\
\hline 12 & $1.86 \mathrm{~m}, 0.95 \mathrm{~m}$ & $1.82 \mathrm{~m}, 0.99 \mathrm{~m}$ & $1.97 \mathrm{~m}, 1.08 \mathrm{~m}$ & $1.96 \mathrm{~m}, 1.05 \mathrm{~m}$ & $1.93 \mathrm{~m}, 1.01 \mathrm{~m}$ & $1.97 \mathrm{~m}, 1.08 \mathrm{~m}$ & $1.98 \mathrm{~m}, 1.05 \mathrm{~m}$ & $\begin{array}{l}2.17 \mathrm{dd}(13.8,2.8) \text {, } \\
\quad 1.38 \mathrm{~m}\end{array}$ \\
\hline 14 & $0.81 \mathrm{~m}$ & $0.83 \mathrm{~m}$ & $0.87 \mathrm{~m}$ & $0.83 \mathrm{~m}$ & $0.85 \mathrm{~m}$ & $0.86 \mathrm{~m}$ & $0.85 \mathrm{~m}$ & $0.92 \mathrm{~m}$ \\
\hline 15 & $1.57 \mathrm{~m}, 1.05 \mathrm{~m}$ & $1.49 \mathrm{~m}, 0.92 \mathrm{~m}$ & $1.62 \mathrm{~m}, 1.14 \mathrm{~m}$ & $1.58 \mathrm{~m}, 1.13 \mathrm{~m}$ & $1.61 \mathrm{~m}, 1.12 \mathrm{~m}$ & $1.61 \mathrm{~m}, 1.12 \mathrm{~m}$ & $1.61 \mathrm{~m}, 1.12 \mathrm{~m}$ & $1.64 \mathrm{~m}, 1.22 \mathrm{~m}$ \\
\hline 16 & $1.59 \mathrm{~m}, 1.29 \mathrm{~m}$ & $1.49 \mathrm{~m}, 1.12 \mathrm{~m}$ & $1.67 \mathrm{~m}, 1.36 \mathrm{~m}$ & $1.65 \mathrm{~m}, 1.36 \mathrm{~m}$ & $1.65 \mathrm{~m}, 1.35 \mathrm{~m}$ & $1.66 \mathrm{~m}, 1.36 \mathrm{~m}$ & $1.65 \mathrm{~m}, 1.36 \mathrm{~m}$ & $1.63 \mathrm{~m}, 1.37 \mathrm{~m}$ \\
\hline 17 & $0.99 \mathrm{~m}$ & $0.99 \mathrm{~m}$ & $1.07 \mathrm{~m}$ & $1.05 \mathrm{~m}$ & $1.04 \mathrm{~m}$ & $1.07 \mathrm{~m}$ & $1.06 \mathrm{~m}$ & $1.04 \mathrm{~m}$ \\
\hline 18 & $0.60 \mathrm{~s}$ & $0.53 \mathrm{~s}$ & $0.73 \mathrm{~s}$ & $0.73 \mathrm{~s}$ & $0.66 \mathrm{~s}$ & $0.72 \mathrm{~s}$ & $0.73 \mathrm{~s}$ & $0.90 \mathrm{~s}$ \\
\hline 19 & $\begin{array}{l}4.17 \mathrm{~d}, 3.65 \mathrm{~d} \\
(9.6)\end{array}$ & $\begin{array}{l}4.79 \mathrm{~d}, 4.21 \mathrm{~d} \\
\quad(9.4)\end{array}$ & $\begin{array}{l}5.07 \mathrm{~d}, 4.32 \mathrm{~d} \\
(11.5)\end{array}$ & $\begin{array}{l}4.36 \mathrm{~d}, 4.07 \mathrm{~d} \\
(11.5)\end{array}$ & $\begin{array}{l}4.32 \mathrm{~d}, 3.77 \mathrm{~d} \\
(9.7)\end{array}$ & $\begin{array}{l}5.07 \mathrm{~d}, 4.32 \mathrm{~d} \\
\quad(11.5)\end{array}$ & $\begin{array}{l}4.37 \mathrm{~d}, 4.09 \mathrm{~d} \\
(11.6)\end{array}$ & $1.63 \mathrm{~s}$ \\
\hline 20 & $1.91 \mathrm{~m}$ & $1.88 \mathrm{~m}$ & $2.00 \mathrm{~m}$ & $1.98 \mathrm{~m}$ & $1.95 \mathrm{~m}$ & $1.96 \mathrm{~m}$ & $1.96 \mathrm{~m}$ & $1.99 \mathrm{~m}$ \\
\hline 21 & $0.90 \mathrm{~d}(6.6)$ & $0.95 \mathrm{~d}(6.7)$ & $0.98 \mathrm{~d}(6.7)$ & $0.97 \mathrm{~d}(6.6)$ & $0.95 \mathrm{~d}(6.6)$ & $0.97 \mathrm{~d}(6.6)$ & $0.97(6.6)$ & $1.00 \mathrm{~d}(6.6)$ \\
\hline 22 & $\begin{array}{l}4.33 \mathrm{dt}(13.3 \\
3.4)\end{array}$ & $\begin{array}{l}4.37 \mathrm{dt}(13.3, \\
3.5)\end{array}$ & $\begin{array}{l}4.38 \mathrm{dt}(13.3 \\
3.4)\end{array}$ & $\begin{array}{l}4.36 \mathrm{dt}(13.3, \\
3.4)\end{array}$ & $\begin{array}{l}4.31 \mathrm{dt}(13.3, \\
3.4)\end{array}$ & $4.31 \mathrm{dt}(13.3,3.4)$ & $\begin{array}{l}4.32 \mathrm{dt}(13.3 \\
3.4)\end{array}$ & $4.39 \mathrm{dt}(13.2,3.5)$ \\
\hline \multirow[t]{2}{*}{23} & $\begin{array}{l}2.42 \text { dd (17.0, } \\
13.3)\end{array}$ & $\begin{array}{l}2.49 \text { dd (18.0, } \\
13.3)\end{array}$ & $\begin{array}{l}2.50 \mathrm{dd}(17.9, \\
13.3)\end{array}$ & $\begin{array}{l}2.48 \text { dd }(18.2, \\
13.3)\end{array}$ & $\begin{array}{l}2.40 \text { dd (18.0, } \\
13.3)\end{array}$ & $\begin{array}{l}2.41 \mathrm{dd}(18.0, \\
13.3)\end{array}$ & $\begin{array}{l}2.41 \mathrm{dd}(18.0, \\
13.3)\end{array}$ & $2.47 \mathrm{dd}(13.2,17.0)$ \\
\hline & $1.91 \mathrm{~m}$ & $2.17 \mathrm{~m}$ & $1.99 \mathrm{~m}$ & $2.16 \mathrm{~m}$ & $1.87 \mathrm{~m}$ & $1.88 \mathrm{~m}$ & $1.88 \mathrm{~m}$ & $1.94 \mathrm{dd}(3.5,17.0)$ \\
\hline 27 & $\begin{array}{l}4.28 \mathrm{~d}, 4.23 \mathrm{~d} \\
(12.5)\end{array}$ & $\begin{array}{l}4.86 \mathrm{~d}, 4.76 \mathrm{~d} \\
\quad(11.8)\end{array}$ & $\begin{array}{l}4.88 \mathrm{~d}, 4.84 \mathrm{~d} \\
(11.8)\end{array}$ & $\begin{array}{l}4.88 \mathrm{~d}, 4.85 \mathrm{~d} \\
(11.9)\end{array}$ & $1.85 \mathrm{~s}$ & $1.85 \mathrm{~s}$ & $1.85 \mathrm{~s}$ & $4.34 \mathrm{br}$ \\
\hline 28 & $1.97 \mathrm{~s}$ & $2.11 \mathrm{~s}$ & $2.05 \mathrm{~s}$ & $2.04 \mathrm{~s}$ & $1.90 \mathrm{~s}$ & $1.91 \mathrm{~s}$ & $1.90 \mathrm{~s}$ & $2.01 \mathrm{~s}$ \\
\hline 4-OAc & & & $2.09 \mathrm{~s}$ & $2.07 \mathrm{~s}$ & & $2.09 \mathrm{~s}$ & $2.08 \mathrm{~s}$ & \\
\hline 19-OAc & & & $2.06 \mathrm{~s}$ & & & $2.06 \mathrm{~s}$ & & \\
\hline 27-OAc & & & $2.03 \mathrm{~s}$ & $2.02 \mathrm{~s}$ & & & & \\
\hline
\end{tabular}

and 2), were obtained by $2 \mathrm{D}$-NMR methods including ${ }^{1} \mathrm{H}-{ }^{1} \mathrm{H}$ COSY, HSQC, HMBC, and ROESY spectra.

Compound 2 was isolated as colorless rod crystals from a $\mathrm{CH}_{2} \mathrm{Cl}_{2}-\mathrm{CH}_{3} \mathrm{C}_{6} \mathrm{H}_{5}$ mixture and was also a major metabolite from the EtOAc-soluble part. Its molecular formula, $\mathrm{C}_{28} \mathrm{H}_{38} \mathrm{O}_{6}$, was determined by HRESIMS and NMR experiments. The IR and NMR $\left({ }^{1} \mathrm{H}\right.$ and ${ }^{13} \mathrm{C}$ ) data (Tables 1 and 2) were similar to those of 1. Analysis of the 1D- and 2D-NMR data for 2 identified resonances consistent with an $\alpha, \beta$-unsaturated ketone in ring $\mathrm{A}\left[{ }^{13} \mathrm{C}: \delta 200.2(\mathrm{C}-1), 133.1(\mathrm{C}-2), 145.4(\mathrm{C}-3) ;{ }^{1} \mathrm{H}: \delta\right.$ $6.23(\mathrm{H}-2, \mathrm{~d}, J=10.4 \mathrm{~Hz}), 7.01(\mathrm{H}-3, \mathrm{dd}, J=10.4,6.4 \mathrm{~Hz})]$, an epoxy in ring $\mathrm{B}\left[{ }^{13} \mathrm{C}: \delta 61.7(\mathrm{C}-5), 62.1(\mathrm{C}-6) ;{ }^{1} \mathrm{H}: \delta 3.25\right.$ (brs, $\mathrm{H}-6)]$, a nine-carbon side chain with a $\delta$-lactone group $\left[{ }^{13} \mathrm{C}: \delta\right.$ 78.4 (C-22), 149.2 (C-24), 122.2 (C-25), 167.3 (C-26); ${ }^{1} \mathrm{H}: \delta$ $4.31(\mathrm{H}-22, \mathrm{dt}, J=13.3,3.4 \mathrm{~Hz})]$, and an oxygenated $\mathrm{C}-19$ $\left[{ }^{13} \mathrm{C}: \delta 62.1 ;{ }^{1} \mathrm{H}: \delta 4.32,3.77(\mathrm{~d}, J=9.7 \mathrm{~Hz})\right]$. The obvious differences between 2 and 1 were the presence of a 27-methyl carbon $\left[{ }^{13} \mathrm{C}: \delta 12.7 ;{ }^{1} \mathrm{H}: 1.85(3 \mathrm{H}, \mathrm{s})\right]$ in 2 and an oxygenated methylene [C-27, ${ }^{13} \mathrm{C}: \delta 56.7 ;{ }^{1} \mathrm{H}: \delta 4.28(1 \mathrm{H}, \mathrm{d}, J=12.5 \mathrm{~Hz})$, $4.23(1 \mathrm{H}, \mathrm{d}, J=12.5 \mathrm{~Hz})]$ in 1 , suggesting that 2 is a 27 -deoxy derivative of 1 . This observation was supported by the ${ }^{13} \mathrm{C}$ NMR chemical shift values of the $\delta$-lactone moiety $\left[\begin{array}{ll}\delta & 149.2\end{array}\right.$ (C-24), 122.2 (C-25), 167.3 (C-26) in 2 and $\delta 154.3$ (C-24), 125.6 (C-25), 167.4 (C-26) in 1], by the NMR data comparison of the side chain moiety of 2 to those of 27-deoxywithanolides, ${ }^{14,15}$ and by HMBC correlations of $\mathrm{H}_{3}-27 / \mathrm{C}-24, \mathrm{C}-25$, and C-26.

Acetylation of 2 with acetic anhydride in pyridine yielded the 4,19-diacetate $(\mathbf{2 a})$ and the 4-monoacetate (2b) (Tables 1 and 2), which confirmed the presence of hydroxy groups at C-4 and C-19 by a high-frequency shift of $\mathrm{H}-4$ (from $\delta 3.63$ in 2 to $\delta 4.79$ in $2 \mathbf{a}$ and to $\delta 4.74$ in $\mathbf{2 b}$ ) and $\mathrm{H}_{2}-19$ (from $\delta 3.77,4.32$ in 2 to $\delta 4.32,5.07$ in $2 \mathrm{a}$ ).

Finally, the structure of $\mathbf{2}$ was confirmed through a singlecrystal X-ray diffraction experiment (Figure 3). Thus, 2 (withalongolide B) was determined as 27-deoxy-19-hydroxywithaferin A.

Compound 3 was isolated as colorless cube crystals from a $\mathrm{CH}_{2} \mathrm{Cl}_{2}-\mathrm{CH}_{3} \mathrm{CN}$ mixture, a minor component from the EtOAc-soluble fraction. Its molecular formula, $\mathrm{C}_{28} \mathrm{H}_{38} \mathrm{O}_{7}$, was determined by HRESIMS and NMR experiments. The NMR data of 3 (Tables 1 and 2) were also akin to those of withaferin A, 16. ${ }^{1,13}$ Analysis of the 1D- and 2D-NMR data of 3 identified resonances consistent with an $\alpha, \beta$-unsaturated ketone in ring $\mathrm{A}$ $\left[{ }^{13} \mathrm{C}: \delta 204.0(\mathrm{C}-1), 131.6(\mathrm{C}-2), 143.2(\mathrm{C}-3) ;{ }^{1} \mathrm{H}: \delta 6.22(\mathrm{H}-2\right.$, d, $J=10.0 \mathrm{~Hz}), 6.96(\mathrm{H}-3, \mathrm{dd}, J=10.0,6.5 \mathrm{~Hz})]$, an epoxy in ring $\mathrm{B}\left[{ }^{13} \mathrm{C}: \delta 64.5(\mathrm{C}-5), 63.0(\mathrm{C}-6) ;{ }^{1} \mathrm{H}: \delta 3.23\right.$ (brs, $\left.\left.\mathrm{H}-6\right)\right]$, and a nine-carbon side chain with a $\delta$-lactone group $\left[{ }^{13} \mathrm{C}: \delta\right.$ 78.9 (C-22), 153.0 (C-24), 125.9 (C-25), 167.2 (C-26); ${ }^{1} \mathrm{H}: \delta$ $4.39(\mathrm{H}-22, \mathrm{dt}, J=13.2,3.5 \mathrm{~Hz})]$. The obvious differences 


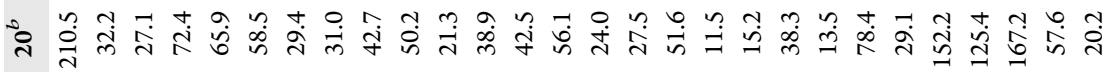

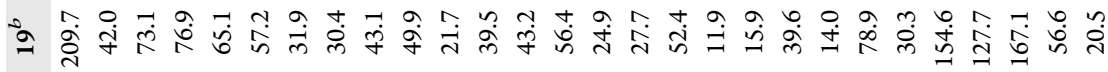

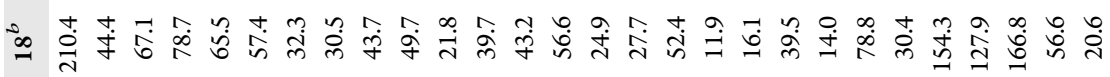

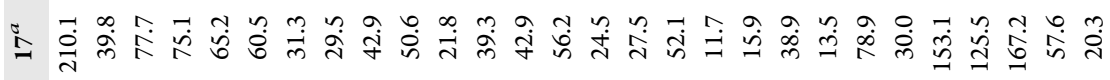

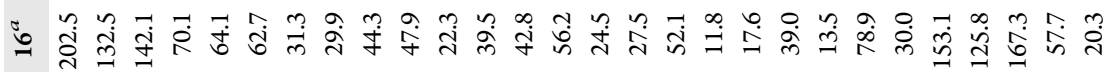

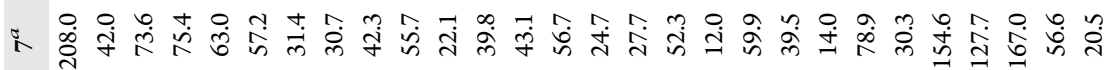

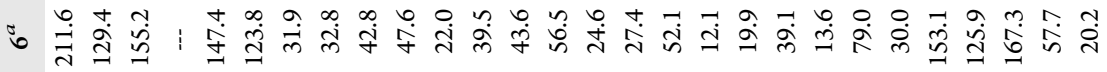

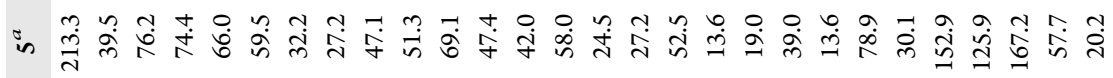

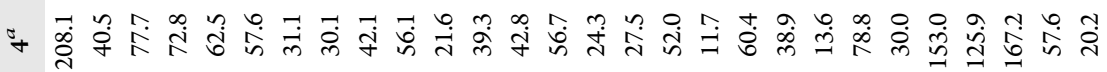

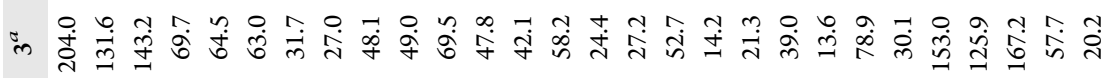

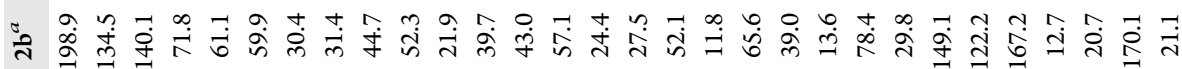

胥

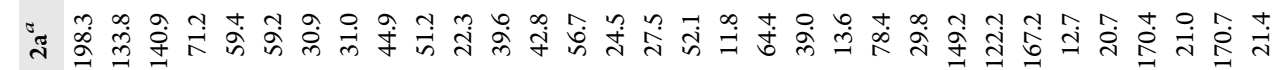

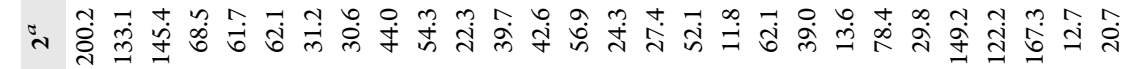

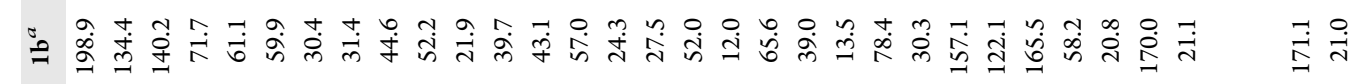

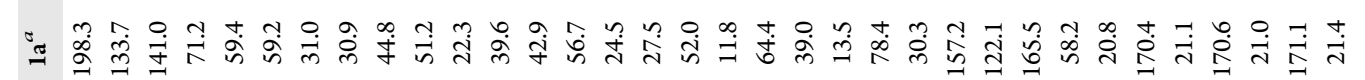

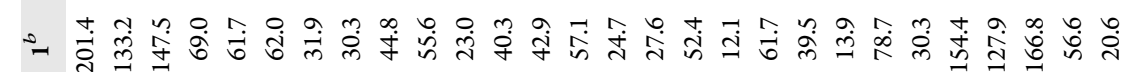

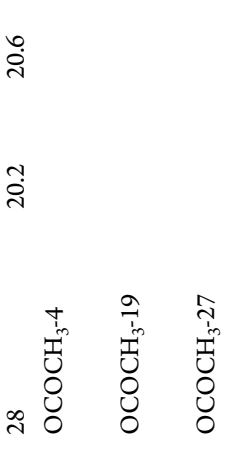

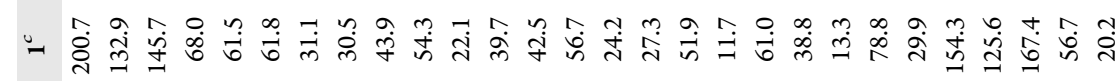


Table 3. ${ }^{1} \mathrm{H}$ NMR Data for Withanolides 4-7 and 16-19 (400 or 500 MHz)

\begin{tabular}{|c|c|c|c|c|c|c|c|c|}
\hline pos. & $4^{a}$ & $5^{a}$ & $6^{a}$ & $7^{b}$ & $16^{a}$ & $17^{a}$ & $18^{b, c}$ & $19^{b}$ \\
\hline \multirow[t]{2}{*}{2} & $\begin{array}{r}\mathrm{H} \beta 2.86 \mathrm{dd} \\
(8.3,16.4)\end{array}$ & $\begin{array}{l}\mathrm{H} \beta 2.86 \mathrm{dd}(6.5 \\
17.5)\end{array}$ & $5.93 \mathrm{~d}(6.4)$ & $\begin{array}{r}\mathrm{H} \beta 3.65 \mathrm{dd} \\
(8.1,18.0)\end{array}$ & $6.18 \mathrm{~d}(10.0)$ & $\begin{array}{l}\mathrm{H} \beta 2.99 \mathrm{dd}(6.3 \\
15.0)\end{array}$ & $\begin{array}{l}\mathrm{H} \beta 3.62 \mathrm{dd}(10.0, \\
17.1)\end{array}$ & $\begin{array}{r}\mathrm{H} \beta 3.62 \mathrm{dd} \\
(9.7,17.6)\end{array}$ \\
\hline & $\begin{array}{r}\mathrm{H} \alpha 2.56 \mathrm{dd} \\
(2.6,16.4)\end{array}$ & $\begin{array}{l}\mathrm{H} \alpha 2.56 \mathrm{dd}(2.2, \\
17.5)\end{array}$ & & $\begin{array}{r}\mathrm{H} \alpha 3.22 \mathrm{dd} \\
(6.2,18.0)\end{array}$ & & $\begin{array}{l}\mathrm{H} \alpha 2.56 \mathrm{dd}(2.2 \\
15.0)\end{array}$ & $\begin{array}{l}\mathrm{H} \alpha 3.02 \mathrm{dd}(5.5 \\
17.1)\end{array}$ & $\begin{array}{r}\mathrm{H} \alpha 3.30 \mathrm{dd} \\
(2.0,17.6)\end{array}$ \\
\hline 3 & $\begin{array}{l}3.70 \text { ddd }(8.3 \text {, } \\
3.4,2.6)\end{array}$ & $\begin{array}{l}3.75 \text { ddd }(6.5,4.0 \\
2.2)\end{array}$ & $7.57 \mathrm{~d}(6.4)$ & 5.61 brt $(8.1)$ & $\begin{array}{l}6.91 \mathrm{dd}(10.0, \\
5.9)\end{array}$ & $\begin{array}{l}3.68 \text { ddd }(6.3 \\
3.2,2.2)\end{array}$ & $4.67 \mathrm{br}$ & $\begin{array}{l}5.62 \text { ddd (9.7, } \\
6.5,2.0)\end{array}$ \\
\hline 4 & $3.42 \mathrm{~d}(3.4)$ & $3.56 \mathrm{~d}(4.0)$ & & $4.54 \mathrm{br}$ & $3.74 \mathrm{~d}(5.9)$ & $3.46 \mathrm{~d}(3.2)$ & $4.05 \mathrm{br}$ & $4.51 \mathrm{br}$ \\
\hline 6 & 3.22 brs & 3.15 brs & $5.76 \mathrm{t}(3.5)$ & 3.37 brs & $3.21 \mathrm{~s}$ & $3.19 \mathrm{~s}$ & $3.30 \mathrm{br}$ & $3.62 \mathrm{br}$ \\
\hline \multirow[t]{2}{*}{7} & $2.25 \mathrm{~m}$ & $2.31 \mathrm{dd}(5.2,14.8)$ & $\begin{array}{l}2.37 \text { ddd }(3.5 \\
8.8,15.0)\end{array}$ & $2.35 \mathrm{~m}$ & $\begin{array}{l}2.12 \text { ddd (2.2, } \\
3.7,14.6)\end{array}$ & $\begin{array}{l}2.14 \text { ddd }(2.2 \text {, } \\
3.7,14.6)\end{array}$ & $\begin{array}{l}2.22 \text { ddd (1.7) } \\
\quad 4.3,15.0)\end{array}$ & $2.07 \mathrm{~m}$ \\
\hline & $1.42 \mathrm{~m}$ & $1.34 \mathrm{~m}$ & $1.70 \mathrm{~m}$ & $2.11 \mathrm{~m}$ & $1.30 \mathrm{~m}$ & $1.31 \mathrm{~m}$ & $\begin{array}{l}1.40 \text { ddd (2.0) } \\
10.2,15.0)\end{array}$ & $1.23 \mathrm{~m}$ \\
\hline 8 & $1.41 \mathrm{~m}$ & $1.70 \mathrm{dq}(4.5,10.8)$ & $1.75 \mathrm{~m}$ & $1.50 \mathrm{~m}$ & $1.39 \mathrm{~m}$ & $1.39 \mathrm{~m}$ & $1.50 \mathrm{~m}$ & $1.41 \mathrm{~m}$ \\
\hline 9 & $1.14 \mathrm{~m}$ & $1.28 \mathrm{~m}$ & $1.17 \mathrm{~m}$ & $1.16 \mathrm{~m}$ & $1.14 \mathrm{~m}$ & $1.16 \mathrm{~m}$ & $1.17 \mathrm{~m}$ & $1.04 \mathrm{~m}$ \\
\hline 11 & $1.27 \mathrm{~m}, 1.18 \mathrm{~m}$ & $3.88 \mathrm{~m}$ & $2.24 \mathrm{~m}, 1.58 \mathrm{~m}$ & $1.57 \mathrm{~m}, 1.34 \mathrm{~m}$ & $1.27 \mathrm{~m}, 1.18 \mathrm{~m}$ & $1.35 \mathrm{~m}$ & $1.52 \mathrm{~m}$ & $1.44 \mathrm{~m}$ \\
\hline 12 & $1.90 \mathrm{~m}, 1.02 \mathrm{~m}$ & $\begin{array}{r}2.15 \mathrm{dd}(13.9 \\
2.4), 1.38 \mathrm{~m}\end{array}$ & $1.99 \mathrm{~m}, 1.18 \mathrm{~m}$ & $1.76 \mathrm{~m}, 1.02 \mathrm{~m}$ & $1.88 \mathrm{~m}, 1.08 \mathrm{~m}$ & $1.88 \mathrm{~m}, 1.08 \mathrm{~m}$ & $1.85 \mathrm{~m}, 1.05 \mathrm{~m}$ & $1.80 \mathrm{~m}, 1.05 \mathrm{~m}$ \\
\hline 14 & $0.95 \mathrm{~m}$ & $0.94 \mathrm{~m}$ & $1.03 \mathrm{~m}$ & $0.91 \mathrm{~m}$ & $0.95 \mathrm{~m}$ & $0.94 \mathrm{~m}$ & $0.93 \mathrm{~m}$ & $0.92 \mathrm{~m}$ \\
\hline 15 & $1.64 \mathrm{~m}, 1.13 \mathrm{~m}$ & $1.66 \mathrm{~m}, 1.21 \mathrm{~m}$ & $1.61 \mathrm{~m}, 1.19 \mathrm{~m}$ & $1.52 \mathrm{~m}, 0.90 \mathrm{~m}$ & $1.64 \mathrm{~m}, 1.13 \mathrm{~m}$ & $1.61 \mathrm{~m}, 1.12 \mathrm{~m}$ & $1.54 \mathrm{~m}, 0.96 \mathrm{~m}$ & $1.54 \mathrm{~m}, 0.92 \mathrm{~m}$ \\
\hline 16 & $1.66 \mathrm{~m}, 1.35 \mathrm{~m}$ & $1.64 \mathrm{~m}, 1.38 \mathrm{~m}$ & $1.64 \mathrm{~m}, 1.35 \mathrm{~m}$ & $1.57 \mathrm{~m}, 1.13 \mathrm{~m}$ & $1.66 \mathrm{~m}, 1.35 \mathrm{~m}$ & $1.64 \mathrm{~m}, 1.31 \mathrm{~m}$ & $1.54 \mathrm{~m}, 1.15 \mathrm{~m}$ & $1.57 \mathrm{~m}, 1.15 \mathrm{~m}$ \\
\hline 17 & $1.07 \mathrm{~m}$ & $1.04 \mathrm{~m}$ & $1.10 \mathrm{~m}$ & $1.13 \mathrm{~m}$ & $1.07 \mathrm{~m}$ & $1.05 \mathrm{~m}$ & $1.07 \mathrm{~m}$ & $1.14 \mathrm{~m}$ \\
\hline 18 & $0.62 \mathrm{~s}$ & $0.85 \mathrm{~s}$ & $0.75 \mathrm{~s}$ & $0.47 \mathrm{~s}$ & $0.67 \mathrm{~s}$ & $0.64 \mathrm{~s}$ & $0.55 \mathrm{~s}$ & $0.52 \mathrm{~s}$ \\
\hline 19 & $\begin{array}{l}4.38 \mathrm{~d}, 3.61 \mathrm{~d} \\
(10.2)\end{array}$ & $1.49 \mathrm{~s}$ & $1.15 \mathrm{~s}$ & $\begin{array}{l}4.80 \mathrm{~d}, 4.01 \mathrm{~d} \\
\quad(9.4)\end{array}$ & $1.38 \mathrm{~s}$ & $1.28 \mathrm{~s}$ & $1.76 \mathrm{~s}$ & $1.69 \mathrm{~s}$ \\
\hline 20 & $1.96 \mathrm{~m}$ & $1.99 \mathrm{~m}$ & $1.99 \mathrm{~m}$ & $1.86 \mathrm{~m}$ & $1.97 \mathrm{~m}$ & $1.97 \mathrm{~m}$ & $1.90 \mathrm{~m}$ & $1.90 \mathrm{~m}$ \\
\hline 21 & $0.95 \mathrm{~d}(6.7)$ & $1.00 \mathrm{~d}(6.7)$ & $1.01 \mathrm{~d}(6.6)$ & $0.95 \mathrm{~d}(6.6)$ & $0.97 \mathrm{~d}(6.6)$ & $0.96 \mathrm{~d}(6.6)$ & $0.97 \mathrm{~d}(6.6)$ & $0.97 \mathrm{~d}(6.6)$ \\
\hline 22 & $\begin{array}{l}4.39 \mathrm{dt}(13.2, \\
3.5)\end{array}$ & $4.39 \mathrm{dt}(13.2,3.5)$ & $\begin{array}{l}4.42 \mathrm{dt}(13.3) \\
3.4)\end{array}$ & $\begin{array}{l}4.38 \mathrm{dt}(13.2, \\
3.3)\end{array}$ & $\begin{array}{l}4.39 \mathrm{dt}(13.2, \\
3.5)\end{array}$ & $\begin{array}{l}4.39 \mathrm{dt}(13.2, \\
3.5)\end{array}$ & $\begin{array}{l}4.39 \mathrm{dt}(13.2 \\
3.3)\end{array}$ & $\begin{array}{l}4.40 \mathrm{dt}(13.2 \text {, } \\
3.3)\end{array}$ \\
\hline \multirow[t]{2}{*}{23} & $\begin{array}{l}2.46 \mathrm{dd}(13.2 \text {, } \\
17.0)\end{array}$ & $\begin{array}{l}2.47 \text { dd }(13.7, \\
17.8)\end{array}$ & $\begin{array}{l}2.48 \mathrm{dd}(13.6, \\
17.6)\end{array}$ & $\begin{array}{l}2.35 \text { dd (13.9) } \\
18.0)\end{array}$ & $\begin{array}{l}2.47 \mathrm{dd}(13.6 \\
17.4)\end{array}$ & $\begin{array}{l}2.47 \mathrm{dd}(13.6, \\
17.4)\end{array}$ & $\begin{array}{l}2.35 \mathrm{dd}(13.4, \\
17.7)\end{array}$ & $\begin{array}{l}2.36 \mathrm{dd}(13.7, \\
17.8)\end{array}$ \\
\hline & $\begin{array}{l}1.93 \mathrm{dd}(3.5 \\
17.0)\end{array}$ & $1.94 \mathrm{dd}(3.2,17.8)$ & $\begin{array}{l}1.98 \mathrm{dd}(3.2, \\
17.6)\end{array}$ & $2.07 \mathrm{~m}$ & $\begin{array}{l}1.94 \mathrm{dd}(3.2 \text {, } \\
17.4)\end{array}$ & $\begin{array}{l}1.94 \mathrm{dd}(3.2 \text {, } \\
17.4)\end{array}$ & $\begin{array}{l}2.01 \mathrm{dd}(3.3, \\
17.7)\end{array}$ & $2.07 \mathrm{~m}$ \\
\hline 27 & $\begin{array}{l}4.36 \mathrm{~d}, 4.32 \mathrm{~d} \\
\quad(12.5)\end{array}$ & $\begin{array}{l}4.37 \mathrm{~d}, 4.31 \mathrm{~d} \\
\quad(12.6)\end{array}$ & $\begin{array}{l}4.37 \mathrm{~d}, 4.32 \mathrm{~d} \\
\quad(12.5)\end{array}$ & $\begin{array}{l}4.85 \mathrm{~d}, 4.75 \mathrm{~d} \\
\quad(11.7)\end{array}$ & $\begin{array}{l}4.36 \mathrm{~d}, 4.31 \mathrm{~d} \\
\quad(12.6)\end{array}$ & $\begin{array}{l}4.36 \mathrm{~d}, 4.31 \mathrm{~d} \\
\quad(12.6)\end{array}$ & $\begin{array}{l}4.80 \mathrm{~d}, 4.78 \mathrm{~d} \\
(11.8)\end{array}$ & $\begin{array}{l}4.85 \mathrm{~d}, 4.75 \mathrm{~d} \\
\quad(11.7)\end{array}$ \\
\hline 28 & $2.02 \mathrm{~s}$ & $2.01 \mathrm{~s}$ & $2.01 \mathrm{~s}$ & $2.09 \mathrm{~s}$ & $2.01 \mathrm{~s}$ & $2.01 \mathrm{~s}$ & $2.10 \mathrm{~s}$ & $2.09 \mathrm{~s}$ \\
\hline 3-OMe & $3.35 \mathrm{~s}$ & $3.34 \mathrm{~s}$ & & & & $3.32 \mathrm{~s}$ & & \\
\hline
\end{tabular}

${ }^{a}$ In $\mathrm{CDCl}_{3} .{ }^{b}$ In $\mathrm{C}_{5} \mathrm{D}_{5} \mathrm{~N} .{ }^{c} \mathrm{OH}-4$ signal $7.75 \mathrm{~s}, \mathrm{OH}-3$ signal 6.91 brs, OH-27 signal 6.61 brs.

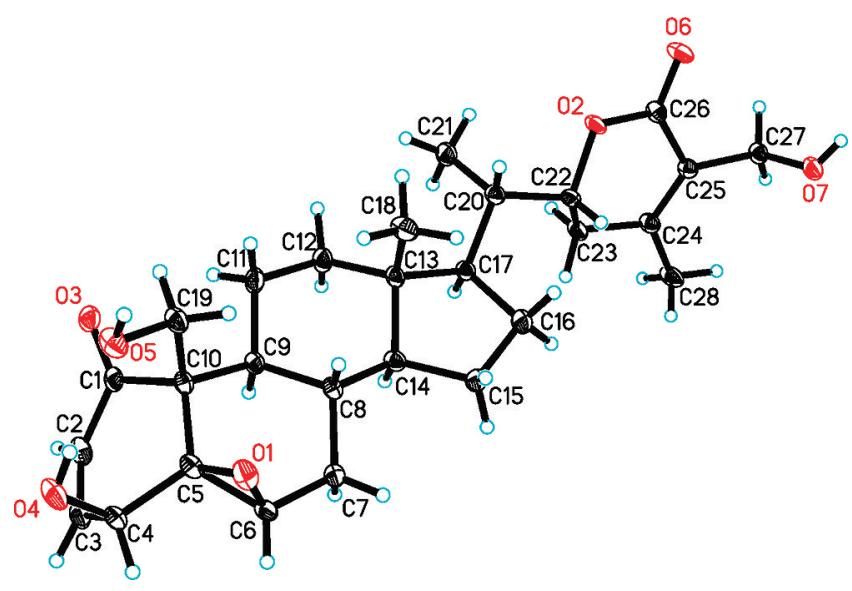

Figure 2. X-ray ORTEP drawing of withalongolide A (1).

between 3 and 16 were the presence of an oxygenated methine $\left[\mathrm{C}-11,{ }^{13} \mathrm{C}: \delta 69.5 ;{ }^{1} \mathrm{H}: 4.15(1 \mathrm{H}, \mathrm{brs})\right]$ in 3 and a lowfrequency methylene $\left[\mathrm{C}-11,{ }^{13} \mathrm{C}: \delta 22.3 ;{ }^{1} \mathrm{H}: \delta 1.27(1 \mathrm{H}, \mathrm{m})\right.$, $1.18(1 \mathrm{H}, \mathrm{m})]$ in 16 , implying that 3 is 11 -hydroxywithaferin $\mathrm{A}$. This observation was supported by the high-frequency shift of C-9 $(\delta 48.1$ in 3 and $\delta 44.3$ in 16) and C-12 ( $\delta 47.8$ in 3 and $\delta$ 39.5 in 16) and the low-frequency shift of C-8 ( $\delta 27.0$ in 3 and

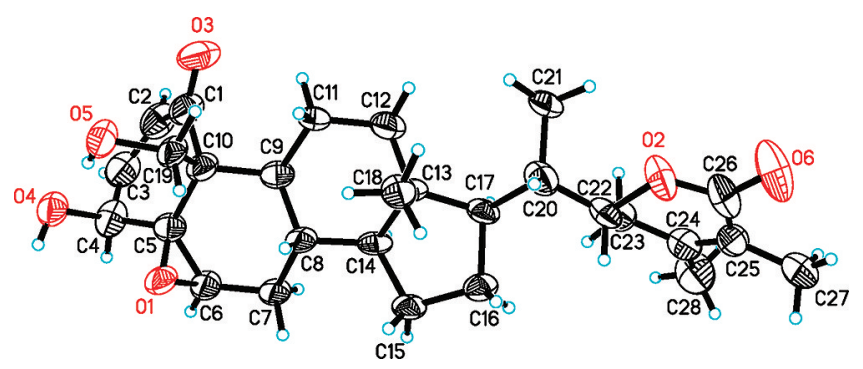

Figure 3. X-ray ORTEP drawing of withalongolide B (2).

$\delta 29.9$ in 16) in the ${ }^{13} \mathrm{C}$ NMR spectrum; by the presence of the fragment $-\mathrm{CH}_{2}-\mathrm{CH}(\mathrm{OH})-\mathrm{CH}-\mathrm{CH}\left(\mathrm{CH}_{2}\right)-\mathrm{CH}-$ (starting with $\mathrm{C}-12$ and ending with $\mathrm{C}-14)$ deduced from ${ }^{1} \mathrm{H}-{ }^{1} \mathrm{H}$ COSY and HSQC experiments; and by the HMBC correlations between $\mathrm{H}_{\alpha}-12(\delta 2.17$, dd, $J=13.8,2.8 \mathrm{~Hz})$ and C-9 $(\delta 48.1)$, C-11 ( $\delta$ 69.5), C-13 ( $\delta$ 42.1), and C-14 ( $\delta$ 58.2). The orientation of the hydroxy group at $\mathrm{C}-11$ was deduced as $\beta$ due to the broad single-peak pattern of $\mathrm{H}-11(\delta 4.15$, brs $)$, the small coupling constant of $3.3 \mathrm{~Hz}$ between $\mathrm{H}-9(\delta 1.25$, dd, $J=10.8$, $3.3 \mathrm{~Hz}$ ) and $\mathrm{H}-11$, and ROESY correlations of $\mathrm{H}-11 / \mathrm{H}-9$ and $\mathrm{H}-11 / \mathrm{H}_{\alpha}-12$. Finally, the structure of 3 was confirmed through a single-crystal X-ray diffraction experiment (Figure 4). Thus, 


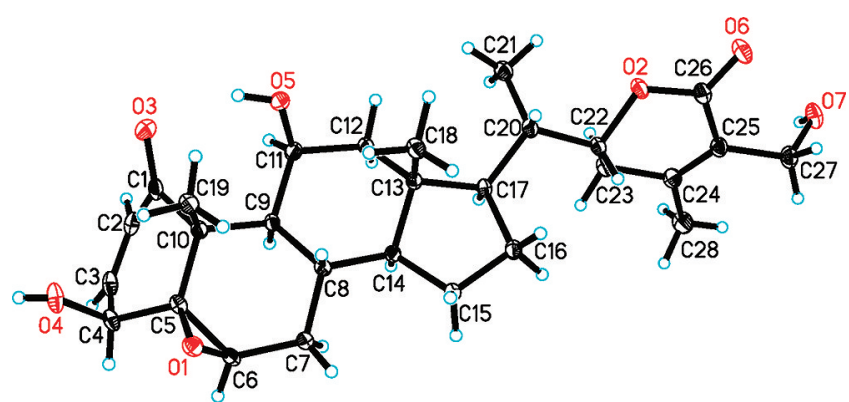

Figure 4. X-ray ORTEP drawing of withalongolide C (3).

the new withanolide 3 (withalongolide $C$ ) was established as $11 \beta$-hydroxywithaferin A.

Compounds $\mathbf{4}$ and $\mathbf{5}$ were isolated as two presumed artifacts. These two compounds were probably formed from withalongolide A (1) and withalongolide $\mathrm{C}$ (3), respectively, by a Michael-type addition due to the use of $\mathrm{CH}_{3} \mathrm{OH}$ during the extraction procedure. It is possible that these compounds are formed in a similar fashion to 2,3 -dihydro-3 $\beta$-methoxywithaferin $A(17)^{1}$ (Tables 2 and 3 ), which was most likely derived from withaferin A (16) during this study. Comparing the NMR data of the methoxy group in $17\left[-\mathrm{OCH}_{3}\right.$ group at $\mathrm{C}-3:{ }^{1} \mathrm{H}: \delta$ $3.32(3 \mathrm{H}, \mathrm{s}) ;{ }^{13} \mathrm{C}: \delta$ 57.0; H-3: $\delta 3.68(1 \mathrm{H}, \mathrm{ddd}, J=6.3,3.2,2.2$ $\mathrm{Hz}) ; \mathrm{C}-3: \delta 77.7]$ with both 4 and $5\left[-\mathrm{OCH}_{3}:{ }^{1} \mathrm{H}: \delta 3.35(3 \mathrm{H}\right.$, s); ${ }^{13} \mathrm{C}: \delta 57.6$; H-3: $\delta 3.70(1 \mathrm{H}, \mathrm{ddd}, J=8.3,3.4,2.6 \mathrm{~Hz})$; C-3: $\delta 77.7$ in 4 and $-\mathrm{OCH}_{3}:{ }^{1} \mathrm{H}: \delta 3.34(3 \mathrm{H}, \mathrm{s}) ;{ }^{13} \mathrm{C}: \delta 57.4 ; \mathrm{H}-3: \delta$ $3.75(1 \mathrm{H}$, ddd, $J=6.5,4.0,2.2 \mathrm{~Hz})$; C-3: $\delta 76.2$ in 5] suggested the presence of a methoxy group at the $\mathrm{C}-3$ positions in 4 and 5. This was confirmed by the presence of a ${ }^{1} \mathrm{H}-{ }^{1} \mathrm{H}$ COSY fragment of $-\mathrm{CH}_{2}-\mathrm{CH}\left(\mathrm{OCH}_{3}\right)-\mathrm{CH}(\mathrm{OH})-$ in ring $\mathrm{A}$ and HMBC correlation of $\mathrm{OCH}_{3} / \mathrm{C}-3$ in both 4 and 5 . The structures of $\mathbf{4}$ (withalongolide D) and $\mathbf{5}$ (withalongolide $\mathrm{E}$ ) were determined by spectroscopic methods, and complete assignments of their NMR data are listed in Tables 2 and 3.

Compound 6 was isolated as colorless cube crystals obtained from a $\mathrm{CH}_{2} \mathrm{Cl}_{2}-\mathrm{CH}_{3} \mathrm{CN}$ mixture. Its molecular formula, $\mathrm{C}_{27} \mathrm{H}_{34} \mathrm{O}_{4}$, was ascertained by HRESIMS and NMR experiments (Tables 2 and 3). Similar to withaferin A (16), it showed signals for four methyl groups $\left[{ }^{13} \mathrm{C}: \delta 20.2(\mathrm{C}-28), 19.9(\mathrm{C}-19)\right.$, 13.6 (C-21), 12.1 (C-18); ${ }^{1} \mathrm{H}: \delta 2.01\left(\mathrm{H}_{3}-28, \mathrm{~s}\right), 1.15\left(\mathrm{H}_{3}-19\right.$, s), $\left.1.01\left(\mathrm{H}_{3}-21, \mathrm{~d}, J=6.6 \mathrm{~Hz}\right), 0.75\left(\mathrm{H}_{3}-18, \mathrm{~s}\right)\right]$, an $\alpha, \beta$ unsaturated ketone in ring $\mathrm{A}\left[{ }^{13} \mathrm{C}: \delta 211.6(\mathrm{C}-1), 129.4(\mathrm{C}-2)\right.$, $155.2(\mathrm{C}-3) ;{ }^{1} \mathrm{H}: \delta 5.93(\mathrm{H}-2, \mathrm{~d}, J=6.4 \mathrm{~Hz}), 7.57(\mathrm{H}-3, \mathrm{~d}, J=$ $6.4 \mathrm{~Hz})]$, and a nine-carbon side chain with an $\alpha, \beta$-unsaturated $\delta$-lactone group $\left[{ }^{13} \mathrm{C}: \delta 57.7(\mathrm{C}-27), 79.0(\mathrm{C}-22), 153.1(\mathrm{C}-\right.$ 24), 125.9 (C-25), 167.3 (C-26); ${ }^{1} \mathrm{H}: \delta 4.42(\mathrm{H}-22, \mathrm{dt}, J=13.3$, $3.4 \mathrm{~Hz}), 4.37(\mathrm{H}-27, \mathrm{~d}, J=12.5 \mathrm{~Hz}), 4.32(\mathrm{H}-27, \mathrm{~d}, J=12.5)]$. A detailed comparison of the NMR data of 6 to those of 16 indicated that both compounds share identical ring $\mathrm{C}, \mathrm{D}$ and side chain moieties, but are different in their $A$ and $B$ rings. A five-membered ring A for $\mathbf{6}$ was proposed on the basis of the following evidence: (1) the unusual chemical shift value of the conjugated ketone carbon (C-1, $\delta$ 211.6); (2) the coupling pattern of $\mathrm{H}-3(\delta 7.57, \mathrm{~d}, J=6.4 \mathrm{~Hz})$ and the small coupling constant of $6.4 \mathrm{~Hz}$ between the olefinic protons $\mathrm{H}-2$ and $\mathrm{H}-3$ when compared to those of $\mathrm{H}-3(6.91, \mathrm{dd}, J=10.0,5.9 \mathrm{~Hz})$ in 16, showing $\mathrm{C}-3$ to be linked with a quaternary carbon in $\mathbf{6}$. This five-membered ring $\mathrm{A}$ and a C-5,6 double bond in ring $\mathrm{B}$ were supported by the HMBC correlations of $\mathrm{H}_{3}-19 / \mathrm{C}-1, \mathrm{C}-5$ (quaternary carbon, $\delta 147.4), \mathrm{C}-9$ ( $\delta 42.8)$, and C-10 ( $\delta 47.6)$; of $\mathrm{H}-2 / \mathrm{C}-1, \mathrm{C}-3, \mathrm{C}-5$, and C-10; and of $\mathrm{H}-3 / \mathrm{C}-1, \mathrm{C}-2, \mathrm{C}-5, \mathrm{C}-6$ (methine, $\delta$ 123.8), and C-10. Finally, the observation was confirmed through a single-crystal X-ray diffraction experiment (Figure 5). Thus, 6 (withalongolide F) was deduced to be

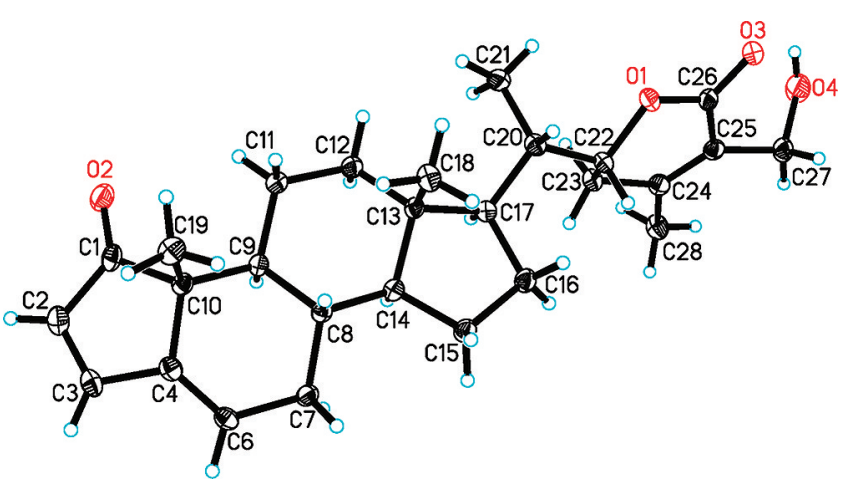

Figure 5. X-ray ORTEP drawing of withalongolide F (6).

A-nor-27-hydroxy-1-oxowitha-2,5,24-trienolide. This 4-norwithanolide with a 2,5-dien-1-one system was reported previously as a semisynthetic product derived from withaferin A by an acid-catalyzed rearrangement. ${ }^{16}$

Compound 7 was a major compound isolated from the $\mathrm{BuOH}$-soluble fraction. Its molecular formula, $\mathrm{C}_{28} \mathrm{H}_{40} \mathrm{O}_{11} \mathrm{~S}$, was determined by HRESIMS and NMR experiments. The NMR data of 7 (Tables 2 and 3) were similar to those of 2,3-dihydro$3 \beta$-O-sulfate-withaferin A (19) (Tables 2 and 3), ${ }^{17}$ another major withanolide isolated from the $\mathrm{BuOH}$-soluble fraction during this study (Figure 1). The obvious differences between 7 and 19 were the presence of an oxygenated methylene [C-19, ${ }^{13} \mathrm{C}: \delta 59.9 ;{ }^{1} \mathrm{H}: \delta 4.80(1 \mathrm{H}, \mathrm{d}, J=9.4 \mathrm{~Hz}), 4.01(1 \mathrm{H}, \mathrm{d}, J=9.4$ $\mathrm{Hz})]$ in 7 and a methyl carbon $\left[\mathrm{C}-19,{ }^{13} \mathrm{C}: \delta 15.9 ;{ }^{1} \mathrm{H}: \delta 1.69\right.$ $(3 \mathrm{H}, \mathrm{s})]$ in the latter, suggesting that 7 is a 19-hydroxy derivative of 19. This observation was supported by the highfrequency shift of C-10 ( $\delta 55.7$ in 7 and $\delta 49.9$ in 19), the lowfrequency shift of C-1 ( $\delta 208.0$ in 7 and $\delta 209.7$ in 19), C-5 $(\delta 63.0$ in 7 and $\delta 65.1$ in 19), and C-9 $(\delta 42.3$ in 7 and $\delta 43.1$ in 19) in the ${ }^{13} \mathrm{C}$ NMR spectrum, and the HMBC correlations of $\mathrm{H}_{2}-19[\delta 4.01(1 \mathrm{H}, \mathrm{d}, J=9.4 \mathrm{~Hz}), 4.80(1 \mathrm{H}, \mathrm{d}$, $J=9.4 \mathrm{~Hz}] / \mathrm{C}-1, \mathrm{C}-5, \mathrm{C}-9$, and C-10 in 7 . Thus, 7 (withalongolide $\mathrm{G}$ ) was determined as 2,3-dihydro-19-hydroxy-3 $\beta$-O-sulfatewithaferin $\mathrm{A}$.

Compound 8 was isolated as a major component from the $\mathrm{BuOH}$-soluble fraction. Its molecular formula, $\mathrm{C}_{40} \mathrm{H}_{58} \mathrm{O}_{15}$, was ascertained by HRESIMS and NMR experiments. The NMR data of 8 (Tables 4 and 5) showed similarities to those of 27-O$\beta$-D-glucopyranosylwithaferin A (15) (sitoindoside IX) ${ }^{18}$ (Tables 4 and 5) isolated during this study, suggesting 8 to be a withanolide saponin. The aglycone of $\mathbf{8}$ was determined to be withaferin $A$, as both $\mathbf{8}$ and $\mathbf{1 5}$ possess the superimposable ${ }^{1} \mathrm{H}$ and ${ }^{13} \mathrm{C}$ NMR signals of the steroid aglycone moieties and both showed the same main LC-MS/MS fragments of $m / z 471$ and 281 due to the presence of a withaferin A moiety. Differing in the presence of only one glucose residue in 15 , two sugar residues were observed in 8 on the basis of the signals of two anomeric carbons [methines, $\delta 105.3\left(\mathrm{C}-1^{\prime}\right)$ and $\left.103.1\left(\mathrm{C}-1^{\prime \prime}\right)\right]$ and their corresponding anomeric protons $\left[\delta 4.97\left(\mathrm{H}-1^{\prime}, 1 \mathrm{H}, \mathrm{d}\right.\right.$, $J=7.8)$ and $\left.5.94\left(\mathrm{H}-1^{\prime \prime}, 1 \mathrm{H}, \mathrm{s}\right)\right]$. Furthermore, the data for 8 suggested that the compound had, besides a glucose unit, an additional five oxygenated carbons (five methines) and one low-frequency methyl group $\left[{ }^{13} \mathrm{C}: \delta 19.0 ;{ }^{1} \mathrm{H}: \delta 1.74(3 \mathrm{H}, \mathrm{d}\right.$, 
Table 4. ${ }^{1} \mathrm{H}$ NMR Data for Withanolides 8-15 in $\mathrm{C}_{5} \mathrm{D}_{5} \mathrm{~N}(500 \mathrm{MHz})$

\begin{tabular}{|c|c|c|c|c|c|c|c|c|}
\hline pos. & $8^{a}$ & $9^{b}$ & $10^{c}$ & $11^{d}$ & $12^{e}$ & $13^{f}$ & $14^{g}$ & $15^{h}$ \\
\hline 1 & & & $4.61 \mathrm{~m}$ & & & & $\begin{array}{l}\mathrm{H} \alpha 2.74 \mathrm{~m}, \mathrm{H} \beta \\
2.10 \mathrm{~m}\end{array}$ & \\
\hline \multirow[t]{2}{*}{2} & $6.43 \mathrm{~d}(10.0)$ & $\begin{array}{l}\mathrm{H} \beta 3.48 \mathrm{dd}(11.0, \\
12.4)\end{array}$ & $\begin{array}{c}\mathrm{H} \alpha 2.73 \mathrm{~d} \\
(18.8)\end{array}$ & $7.14 \mathrm{~d}(7.7)$ & $3.01 \mathrm{dd}(7.1,15.5)$ & $\begin{array}{l}2.94 \mathrm{dd}(8.1, \\
15.2)\end{array}$ & $\begin{array}{l}\mathrm{H} \alpha 1.96 \mathrm{~m}, \mathrm{H} \beta \\
1.80 \mathrm{~m}\end{array}$ & $6.43 \mathrm{~d}(10.0)$ \\
\hline & & $\begin{array}{c}\mathrm{H} \alpha 3.26 \text { ddd }(1.5 \\
5.3,12.4)\end{array}$ & $\begin{array}{l}\mathrm{H} \beta 2.35 \mathrm{dd} \\
\quad(10.2,18.8)\end{array}$ & & $2.91 \mathrm{dd}(3.7,15.5)$ & $\begin{array}{l}2.91 \mathrm{dd}(4.1, \\
15.2)\end{array}$ & & \\
\hline 3 & $\begin{array}{l}7.25 \text { dd (10.0, } \\
6.3)\end{array}$ & $4.29 \mathrm{~m}$ & $4.84 \mathrm{~m}$ & 7.34 t (7.7) & $4.58 \mathrm{~m}$ & $4.47 \mathrm{~m}$ & $4.33 \mathrm{br}$ & $\begin{array}{l}7.25 \mathrm{dd}(10.0, \\
6.3)\end{array}$ \\
\hline \multirow[t]{2}{*}{4} & $\begin{array}{l}4.05 \mathrm{dd}(6.3, \\
3.8)\end{array}$ & $\begin{array}{l}\mathrm{H} \beta 3.07 \mathrm{dt}(2.0 \\
12.2)\end{array}$ & $\mathrm{H} \beta 2.95 \mathrm{t}(12.5)$ & $7.87 \mathrm{~d}(7.7)$ & $3.63 \operatorname{td}(3.2,18.0)$ & $\begin{array}{l}2.68 \mathrm{dd}(5.9, \\
16.8)\end{array}$ & $\mathrm{H} \alpha 2.90 \mathrm{~d}(15.8)$ & $\begin{array}{l}4.05 \mathrm{dd}(6.3, \\
3.7)\end{array}$ \\
\hline & & $\begin{array}{c}\mathrm{H} \alpha 2.99 \text { ddd }(1.5 \\
5.5,12.2)\end{array}$ & $\begin{array}{r}\mathrm{H} \alpha 2.88 \mathrm{dd} \\
(12.5,5.0)\end{array}$ & & $2.92 \mathrm{~m}$ & $\begin{array}{c}2.58 \mathrm{td} \\
16.8)\end{array}(2.7$ & $\begin{array}{c}\mathrm{H} \beta 2.81 \mathrm{dd}(2.2, \\
15.8)\end{array}$ & \\
\hline 6 & $3.28 \mathrm{~s}$ & 5.75 brd (5.3) & 5.92 brd (4.5) & $\begin{array}{l}5.26 \mathrm{dt}(11.0, \\
6.5)\end{array}$ & $4.69 \mathrm{~m}$ & $\begin{array}{l}\mathrm{H} \alpha 2.26 \mathrm{~m}, \mathrm{H} \beta \\
2.09 \mathrm{~m}\end{array}$ & & $3.28 \mathrm{~s}$ \\
\hline \multirow[t]{2}{*}{7} & $\begin{array}{l}2.13 \mathrm{dt}(13.0, \\
1.8)\end{array}$ & $1.92 \mathrm{~m}, 1.53 \mathrm{~m}$ & $\begin{array}{l}\mathrm{H} \alpha 1.66 \mathrm{dd} \\
\quad(11.0,16.0)\end{array}$ & $1.63 \mathrm{q}(11.0)$ & $2.23 \mathrm{~m}$ & $1.98 \mathrm{~m}, 1.53 \mathrm{~m}$ & $\begin{array}{l}2.47 \mathrm{dd}(3.6 \\
16.0)\end{array}$ & $\begin{array}{l}2.13 \mathrm{dt}(13.0, \\
1.8)\end{array}$ \\
\hline & $\begin{array}{l}1.30 \mathrm{dd}(11.5, \\
13.0)\end{array}$ & & $\mathrm{H} \beta 2.02 \mathrm{~m}$ & $\begin{array}{l}2.32 \mathrm{dd}(6.5, \\
11.0)\end{array}$ & & & $2.00 \mathrm{~m}$ & $\begin{array}{l}1.30 \mathrm{dd}(11.5, \\
13.0)\end{array}$ \\
\hline 8 & $1.58 \mathrm{~m}$ & $1.74 \mathrm{dt}(5.3,10.7)$ & $2.20 \mathrm{~m}$ & $1.73 \mathrm{q}(11.0)$ & $1.48 \mathrm{~m}$ & $1.24 \mathrm{~m}$ & $1.62 \mathrm{~m}$ & $1.57 \mathrm{~m}$ \\
\hline 9 & $1.06 \mathrm{~m}$ & $1.94 \mathrm{~m}$ & $2.32 \mathrm{~m}$ & $2.71 \mathrm{t}(11.0)$ & $2.20 \mathrm{~m}$ & $2.04 \mathrm{~m}$ & $1.86 \mathrm{~m}$ & $1.06 \mathrm{~m}$ \\
\hline 11 & $2.02 \mathrm{~m}, 1.57 \mathrm{~m}$ & $2.37 \mathrm{~m}, 1.96 \mathrm{~m}$ & $2.15 \mathrm{~m}, 1,98 \mathrm{~m}$ & $3.68 \mathrm{~m}, 1.46 \mathrm{~m}$ & $2.96 \mathrm{~m}, 1.17 \mathrm{~m}$ & $2.80 \mathrm{~m}, 2.34 \mathrm{~m}$ & $1.84 \mathrm{~m}, 1.24 \mathrm{~m}$ & $2.02 \mathrm{~m}, 1.57 \mathrm{~m}$ \\
\hline 12 & $1.83 \mathrm{~m}, 1.03 \mathrm{~m}$ & $1.95 \mathrm{~m}, 1.26 \mathrm{~m}$ & $1.95 \mathrm{~m}, 1.02 \mathrm{~m}$ & $1.95 \mathrm{~m}, 1.30 \mathrm{~m}$ & $1.83 \mathrm{~m}, 1.17 \mathrm{~m}$ & $1.82 \mathrm{~m}, 1.13 \mathrm{~m}$ & $1.85 \mathrm{~m}, 1.03 \mathrm{~m}$ & $1.85 \mathrm{~m}, 1.02 \mathrm{~m}$ \\
\hline 14 & $0.86 \mathrm{~m}$ & $0.97 \mathrm{~m}$ & $0.86 \mathrm{~m}$ & $1.10 \mathrm{~m}$ & $0.95 \mathrm{~m}$ & $0.90 \mathrm{~m}$ & $0.88 \mathrm{~m}$ & $0.86 \mathrm{~m}$ \\
\hline 15 & $1.50 \mathrm{~m}, 0.96 \mathrm{~m}$ & $1.50 \mathrm{~m}, 1.02 \mathrm{~m}$ & $1.49 \mathrm{~m}, 1.06 \mathrm{~m}$ & $1.52 \mathrm{~m}, 1.12 \mathrm{~m}$ & $1.45 \mathrm{~m}, 1.02 \mathrm{~m}$ & $1.44 \mathrm{~m}, 1.02 \mathrm{~m}$ & $1.33 \mathrm{~m}, 0.88 \mathrm{~m}$ & $1.50 \mathrm{~m}, 0.95 \mathrm{~m}$ \\
\hline 16 & $1.49 \mathrm{~m}, 1.11 \mathrm{~m}$ & $1.50 \mathrm{~m}, 1.14 \mathrm{~m}$ & $1.91 \mathrm{~m}, 1.24 \mathrm{~m}$ & $1.98 \mathrm{~m}, 1.27 \mathrm{~m}$ & $\begin{array}{l}1.95 \mathrm{~m}, 1 . \text { Twenty- } \\
\text { three m }\end{array}$ & $1.95 \mathrm{~m}, 1.23 \mathrm{~m}$ & $1.91 \mathrm{~m}, 1.21 \mathrm{~m}$ & $1.49 \mathrm{~m}, 1.11 \mathrm{~m}$ \\
\hline 17 & $0.99 \mathrm{~m}$ & $1.05 \mathrm{~m}$ & $1.04 \mathrm{~m}$ & $1.12 \mathrm{~m}$ & $1.07 \mathrm{~m}$ & $1.07 \mathrm{~m}$ & $1.06 \mathrm{~m}$ & $0.99 \mathrm{~m}$ \\
\hline 18 & $0.57 \mathrm{~s}$ & $0.67 \mathrm{~s}$ & $0.80 \mathrm{~s}$ & $0.70 \mathrm{~m}$ & $0.59 \mathrm{~s}$ & $0.58 \mathrm{~s}$ & $0.50 \mathrm{~s}$ & $0.57 \mathrm{~s}$ \\
\hline 19 & $1.87 \mathrm{~s}$ & $\begin{array}{c}4.30 \mathrm{~m}, 4.23 \mathrm{dd} \\
(3.9,12.3)\end{array}$ & $\begin{array}{l}4.32 \mathrm{~d}, 4.11 \mathrm{~d} \\
(11.0)\end{array}$ & & & & & $1.86 \mathrm{~s}$ \\
\hline 20 & $1.88 \mathrm{~m}$ & $1.90 \mathrm{~m}$ & $1.98 \mathrm{~m}$ & $2.01 \mathrm{~m}$ & $1.96 \mathrm{~m}$ & $1.96 \mathrm{~m}$ & $1.96 \mathrm{~m}$ & $1.88 \mathrm{~m}$ \\
\hline 21 & $0.96 \mathrm{~d}(6.6)$ & $0.97 \mathrm{~d}(6.6)$ & $0.99 \mathrm{~d}(6.6)$ & $1.01 \mathrm{~d}(6.6)$ & $0.97 \mathrm{~d}(6.6)$ & $0.96 \mathrm{~d}(6.6)$ & $0.99 \mathrm{~d}(6.6)$ & $0.95 \mathrm{~d}(6.6)$ \\
\hline 22 & $4.34 \mathrm{~m}$ & $4.40 \mathrm{dt}(13.2,3.4)$ & $4.25 \mathrm{~m}$ & $\begin{array}{l}4.55 \mathrm{dt}(13.2, \\
3.4)\end{array}$ & $4.53 \mathrm{dt}(13.2,3.4)$ & $\begin{array}{l}4.53 \mathrm{dt}(13.2, \\
3.4)\end{array}$ & $\begin{array}{l}4.53 \mathrm{dt}(13.2, \\
3.4)\end{array}$ & $\begin{array}{l}4.34 \mathrm{dt}(13.2, \\
3.4)\end{array}$ \\
\hline \multirow[t]{2}{*}{23} & $\begin{array}{l}2.27 \mathrm{dd}(13.3, \\
18.0)\end{array}$ & $2.34 \mathrm{dd}(18.0,14.0)$ & $2.78 \mathrm{~m}, 2.33 \mathrm{~m}$ & $\begin{array}{l}2.83 \mathrm{dd}(18.0, \\
2.2)\end{array}$ & $2.81 \mathrm{dd}(18.0,2.2)$ & $\begin{array}{l}2.81 \mathrm{dd}(18.0, \\
2.2)\end{array}$ & $\begin{array}{l}2.81 \mathrm{dd}(18.0, \\
2.2)\end{array}$ & $\begin{array}{l}2.28 \mathrm{dd}(13.3, \\
18.0)\end{array}$ \\
\hline & $\begin{array}{l}1.98 \text { dd (3.1, } \\
18.0)\end{array}$ & $2.03 \mathrm{dd}(3.1,18.0)$ & & $\begin{array}{l}2.34 \text { dd }(18.0 \\
14.0)\end{array}$ & $\begin{array}{l}2.35 \text { dd }(18.0 \\
14.0)\end{array}$ & $\begin{array}{l}2.35 \text { dd (18.0, } \\
14.0)\end{array}$ & $\begin{array}{l}2.37 \mathrm{dd}(18.0, \\
14.0)\end{array}$ & $\begin{array}{l}1.98 \text { dd }(3.1, \\
18.0)\end{array}$ \\
\hline 27 & $\begin{array}{l}5.02 \mathrm{~d}, 4.80 \mathrm{~d} \\
\quad(10.8)\end{array}$ & $\begin{array}{l}4.88 \mathrm{~d}, 4.78 \mathrm{~d} \\
(11.0)\end{array}$ & $2.04 \mathrm{~s}$ & $2.05 \mathrm{~s}$ & $2.05 \mathrm{~s}$ & $2.05 \mathrm{~s}$ & $2.06 \mathrm{~s}$ & $\begin{array}{l}5.07 \mathrm{~d}, 4.86 \mathrm{~d} \\
(10.8)\end{array}$ \\
\hline 28 & $2.07 \mathrm{~s}$ & $2.14 \mathrm{~s}$ & $\begin{array}{l}4.87 \mathrm{~d}, 4.49 \mathrm{~d} \\
(13.5)\end{array}$ & $\begin{array}{l}4.89 \mathrm{~d}, 4.47 \mathrm{~d} \\
(13.5)\end{array}$ & $\begin{array}{l}4.89 \mathrm{~d}, 4.49 \mathrm{~d} \\
(13.5)\end{array}$ & $\begin{array}{l}4.89 \mathrm{~d}, 4.49 \mathrm{~d} \\
(13.5)\end{array}$ & $\begin{array}{l}4.90 \mathrm{~d}, 4.50 \mathrm{~d} \\
(13.5)\end{array}$ & $2.10 \mathrm{~s}$ \\
\hline $1^{\prime}$ & $4.97 \mathrm{~d}(7.8)$ & $5.08 \mathrm{~d}(7.8)$ & $4.84 \mathrm{~d}(7.8)$ & $4.84 \mathrm{~d}(7.8)$ & $4.84 \mathrm{~d}(7.8)$ & $4.84 \mathrm{~d}(7.8)$ & $4.85 \mathrm{~d}(7.8)$ & $5.06 \mathrm{~d}(7.8)$ \\
\hline $2^{\prime}$ & $\begin{array}{l}4.01 \mathrm{td}(7.8, \\
3.6)\end{array}$ & $4.05 \mathrm{t}(7.8)$ & $4.10 \mathrm{~m}$ & $4.10 \mathrm{~m}$ & $4.10 \mathrm{~m}$ & $4.10 \mathrm{~m}$ & $\begin{array}{l}4.11 \mathrm{dd}(7.8, \\
7.0)\end{array}$ & $4.08 \mathrm{t}(7.8)$ \\
\hline $3^{\prime}$ & $4.23 \mathrm{~m}$ & $4.30 \mathrm{~m}$ & $4.25 \mathrm{~m}$ & $4.25 \mathrm{~m}$ & $4.25 \mathrm{~m}$ & $4.25 \mathrm{~m}$ & $4.25 \mathrm{~m}$ & $4.31 \mathrm{~m}$ \\
\hline $4^{\prime}$ & $4.51 \mathrm{t}(9.0)$ & $4.31 \mathrm{~m}$ & $4.24 \mathrm{~m}$ & $4.24 \mathrm{~m}$ & $4.24 \mathrm{~m}$ & $4.24 \mathrm{~m}$ & $4.24 \mathrm{~m}$ & $4.30 \mathrm{~m}$ \\
\hline $5^{\prime}$ & $\begin{array}{l}3.75 \text { ddd }(2.5 \\
5.0,9.0)\end{array}$ & $\begin{array}{l}3.97 \text { ddd }(2.5,5.0 \text {, } \\
9.0)\end{array}$ & $3.99 \mathrm{~m}$ & $4.00 \mathrm{~m}$ & $4.00 \mathrm{~m}$ & $4.00 \mathrm{~m}$ & $4.00 \mathrm{~m}$ & $\begin{array}{l}4.00 \text { ddd }(2.5 \\
5.6,9.0)\end{array}$ \\
\hline \multirow[t]{2}{*}{$6^{\prime}$} & $4.31 \mathrm{~m}, 4.16 \mathrm{~m}$ & $\begin{array}{l}4.54 \text { ddd }(2.5,5.0 \text {, } \\
11.6)\end{array}$ & $4.62 \mathrm{~m}$ & $\begin{array}{l}4.62 \text { ddd }(2.0 \\
5.6,11.6)\end{array}$ & $\begin{array}{l}4.62 \text { ddd }(2.0,5.6 \\
11.6)\end{array}$ & $\begin{array}{l}4.62 \text { ddd }(2.0 \\
5.6,11.6)\end{array}$ & $\begin{array}{l}4.62 \text { ddd }(2.0, \\
5.6,11.6)\end{array}$ & $\begin{array}{l}4.60 \text { ddd }(2.5, \\
5.6,11.5)\end{array}$ \\
\hline & & $4.42 \operatorname{td}(5.0,11.6)$ & $4.42 \mathrm{~m}$ & $\begin{array}{l}4.42 \mathrm{td}(5.6, \\
11.6)\end{array}$ & $4.42 \operatorname{td}(5.6,11.6)$ & $\begin{array}{l}4.42 \mathrm{td}(5.6 \\
11.6)\end{array}$ & $\begin{array}{l}4.42 \mathrm{td}(5.6, \\
11.6)\end{array}$ & $\begin{array}{l}4.44 \mathrm{td}(5.6 \\
11.5)\end{array}$ \\
\hline
\end{tabular}

${ }^{a} \mathrm{H}-1 " 5.94$ s, H-2" $4.73 \mathrm{~s}, \mathrm{H}-3 " 4.60$ br, H-4" 4.38 dd (4.1, 9.9), H-5" 5.06 m, H-6" 1.74 d (6.1), OH-4 $7.87 \mathrm{~d}(3.8)$, OH-2' 7.36 d (3.5), OH-2" 6.84 s,

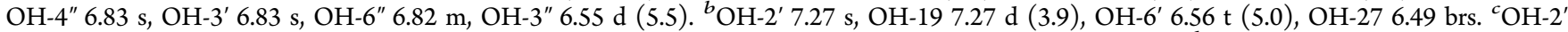
7.51, OH-3' 7.36 s, OH-4' 7.24 s, OH-6' 6.52 t (5.0), OH-3 6.20 d (5.0), OH-1 5.97 d (5.0), OH-19 5.96 brs. ${ }^{d}$ OH-1 11.33 s, OH-2' 7.45 d (4.5), OH-3' 7.35 brs, OH-4' 7.25 brs, OH-6 6.81 d (6.5), OH-6' 6.53 t (5.6). ${ }^{e} \mathrm{OH}-2^{\prime} 7.54$ d (4.3), OH-3' 7.34 brs, OH-4' 7.26 brs, OH-6 6.93 d (6.5), OH36.84 (4.0), OH-6' 6.53 t (5.6). ${ }^{f} \mathrm{OH}-2^{\prime} 7.54 \mathrm{~d}(4.2), \mathrm{OH}-3^{\prime} 7.34$ brs, OH-4' 7.26 brs, OH-3 $6.81 \mathrm{~d}(4.1), \mathrm{OH}-6^{\prime} 6.53 \mathrm{t}(5.5) .{ }^{g} \mathrm{OH}-2^{\prime} 7.49$ brs, OH-3' 7.38 brs, OH-4' 7.28 brs, OH-6' 6.53 t (5.6), OH-3 6.28 brs. ${ }^{h} \mathrm{OH}-47.86$ d (3.7), OH-3' 7.22 brs, OH-4' 7.28 brs, OH-2' 7.21 brs, OH-6' 6.47 t (5.6), OH-3 6.28 brs.

$J=6.1 \mathrm{~Hz}$ )], corresponding to a rhamnose in the pyranose form. The rhamnose moiety was deduced by the detailed comparison of the NMR data of 8 with those of rutin $22\{3-O-[\alpha-\mathrm{L}-$ rhamnopyranosyl-( $1 \rightarrow 6)]$ - $\beta$-D-glucopyranosylquercetin $\}$ also isolated in this study and confirmed from the ${ }^{1} \mathrm{H}-{ }^{1} \mathrm{H}$ COSY,
HSQC, and HMBC spectra when starting with the characteristic methyl group [C-6", ${ }^{13} \mathrm{C}: \delta 19.0 ;{ }^{1} \mathrm{H}: \delta 1.74(3 \mathrm{H}, \mathrm{d}, J=6.1$ $\mathrm{Hz})]$. The $\alpha$-anomeric configuration of the rhamnose unit was assigned from the small coupling constant between $\mathrm{H}-1$ " $(1 \mathrm{H}, \delta$ 5.94, s) and $\mathrm{H}-2^{\prime \prime}(1 \mathrm{H}, \delta 4.73, \mathrm{~s})$. Furthermore, the rhamnose 
Table 5. ${ }^{13} \mathrm{C}$ NMR Data for Withanolides 8-15 in $\mathrm{C}_{5} \mathrm{D}_{5} \mathrm{~N}(125 \mathrm{MHz})$

\begin{tabular}{|c|c|c|c|c|c|c|c|c|}
\hline pos. & $8^{a}$ & 9 & 10 & 11 & 12 & 13 & 14 & 15 \\
\hline 1 & 203.1 & 208.9 & 69.5 & 157.8 & 199.4 & 198.3 & 25.6 & 203.1 \\
\hline 2 & 132.8 & 49.6 & 41.7 & 115.1 & 49.4 & 49.7 & 30.6 & 132.8 \\
\hline 3 & 145.6 & 75.9 & 66.6 & 127.4 & 66.3 & 66.1 & 64.7 & 145.6 \\
\hline 4 & 70.8 & 39.9 & 44.4 & 119.3 & 36.9 & 41.9 & 32.9 & 70.8 \\
\hline 5 & 65.0 & 132.8 & 137.8 & 146.2 & 156.4 & 153.6 & 130.4 & 65.0 \\
\hline 6 & 60.6 & 129.1 & 127.0 & 70.7 & 71.2 & 33.8 & 198.6 & 60.6 \\
\hline 7 & 32.2 & 31.9 & 32.6 & 38.3 & 37.3 & 26.4 & 44.0 & 32.2 \\
\hline 8 & 30.7 & 33.5 & 33.8 & 39.0 & 37.5 & 39.9 & 40.0 & 30.7 \\
\hline 9 & 45.1 & 43.6 & 42.4 & 46.6 & 44.3 & 43.6 & 46.6 & 45.1 \\
\hline 10 & 49.0 & 60.2 & 48.2 & 127.8 & 136.5 & 136.1 & 158.7 & 49.0 \\
\hline 11 & 22.2 & 24.1 & 22.3 & 27.1 & 26.4 & 26.6 & 25.1 & 22.2 \\
\hline 12 & 39.9 & 40.6 & 40.7 & 41.5 & 41.0 & 41.0 & 40.2 & 39.9 \\
\hline 13 & 43.1 & 43.5 & 43.6 & 44.2 & 43.9 & 44.1 & 43.3 & 43.1 \\
\hline 14 & 56.5 & 57.0 & 57.5 & 54.9 & 54.2 & 54.9 & 54.8 & 56.5 \\
\hline 15 & 24.9 & 25.0 & 25.2 & 24.7 & 24.5 & 24.5 & 24.0 & 24.9 \\
\hline 16 & 27.6 & 27.6 & 27.8 & 27.7 & 27.6 & 27.7 & 27.5 & 27.6 \\
\hline 17 & 52.4 & 52.5 & 52.6 & 52.9 & 52.7 & 52.7 & 52.3 & 52.4 \\
\hline 18 & 12.0 & 12.5 & 12.6 & 12.9 & 12.6 & 12.7 & 12.2 & 12.0 \\
\hline 19 & 17.7 & 63.7 & 63.9 & & & & & 17.7 \\
\hline 20 & 39.5 & 39.6 & 39.9 & 40.0 & 39.9 & 39.9 & 39.8 & 39.5 \\
\hline 21 & 13.9 & 13.9 & 14.1 & 13.9 & 13.9 & 13.9 & 14.0 & 13.9 \\
\hline 22 & 78.6 & 78.9 & 79.7 & 79.6 & 79.6 & 79.6 & 79.5 & 78.7 \\
\hline 23 & 30.4 & 30.3 & 25.2 & 25.2 & 25.2 & 25.2 & 25.2 & 30.4 \\
\hline 24 & 157.4 & 154.5 & 148.8 & 148.7 & 148.8 & 148.7 & 148.7 & 157.4 \\
\hline 25 & 124.3 & 127.8 & 125.2 & 125.3 & 125.2 & 125.2 & 125.2 & 124.4 \\
\hline 26 & 166.3 & 166.9 & 167.1 & 167.1 & 167.1 & 167.1 & 167.1 & 166.4 \\
\hline 27 & 64.0 & 56.6 & 13.0 & 12.9 & 12.9 & 12.9 & 12.9 & 63.9 \\
\hline 28 & 21.0 & 20.6 & 67.1 & 66.9 & 67.0 & 67.0 & 67.0 & 21.0 \\
\hline $1^{\prime}$ & 105.3 & 103.5 & 103.5 & 103.4 & 103.5 & 103.5 & 103.5 & 105.4 \\
\hline $2^{\prime}$ & 75.9 & 75.6 & 75.4 & 75.4 & 75.4 & 75.4 & 75.4 & 75.7 \\
\hline $3^{\prime}$ & 77.1 & 79.1 & 79.0 & 79.0 & 79.0 & 79.0 & 79.1 & 79.0 \\
\hline $4^{\prime}$ & 78.5 & 71.9 & 72.1 & 72.1 & 72.1 & 72.1 & 72.1 & 72.1 \\
\hline $5^{\prime}$ & 77.8 & 79.1 & 79.3 & 79.3 & 79.3 & 79.3 & 79.3 & 79.1 \\
\hline $6^{\prime}$ & 61.9 & 63.0 & 63.3 & 63.3 & 63.3 & 63.3 & 63.3 & 63.2 \\
\hline
\end{tabular}

was confirmed to be attached at C-4' $(\delta$ 78.5) on the basis of HMBC correlations of $\mathrm{H}-1^{\prime \prime} / \mathrm{C}-4^{\prime}$ and $\mathrm{H}-4^{\prime} / \mathrm{C}-1^{\prime \prime}$, also supported by the glycosylation shifts of C-4' $(\delta 78.5$ in 8 and $\delta 72.1$ in 15), C-3' $(\delta 77.1$ in 8 and $\delta 79.0$ in 15), and C-5' ( $\delta 77.8$ in 8 and $\delta 79.1$ in 15). Thus, the structure of $\mathbf{8}$ (withalongolide $\mathrm{H}$ ) was determined as $27-O-[\alpha$-L-rhamnopyranosyl $(1 \rightarrow 4)]$ - $\beta$-D-glucopyranosylwithaferin A.

Compounds 9-14 were isolated as the minor components from the $\mathrm{BuOH}$-soluble fraction. Withanolide 9 was assigned a molecular formula of $\mathrm{C}_{34} \mathrm{H}_{50} \mathrm{O}_{11}$ by HRESIMS and NMR experiments. Its NMR data (Tables 4 and 5) exhibited a close resemblance to those of withalongolide $A(1)$, possessing the same nine-carbon side chain with an $\alpha, \beta$-unsaturated $\delta$-lactone, identical rings $\mathrm{C}$ and $\mathrm{D}$, and an oxygenated $\mathrm{C}-19$ methylene group. In addition, the remaining rings $\mathrm{A}$ and $\mathrm{B}$ showed similarities to those of 3-O- $\beta$-D-glucopyranosyl-20,27-dihydroxy-1-oxowitha-5,24-dienolide, a withanolide saponin reported from Physalis peruviana, ${ }^{19}$ with the following signals: (1) the occurrence of a ketone $(\delta 208.9, \mathrm{C}-1)$ and a double bond $\left[{ }^{13} \mathrm{C}\right.$ : C-5 quaternary carbon, $\delta 132.8$, and C-6 methine, $\delta$ 129.1 ; ${ }^{1} \mathrm{H}$ : $\delta 5.75(1 \mathrm{H}$, brd, $\left.J=5.3 \mathrm{~Hz}, \mathrm{H}-6)\right]$; (2) a glucose moiety attached to $\mathrm{C}-3$ in ring $\mathrm{A}\left[{ }^{13} \mathrm{C}: \delta 75.9(\mathrm{CH}, \mathrm{C}-3)\right.$; characteristic signals for glucose: $\delta 103.5\left(\mathrm{CH}, \mathrm{C}-1^{\prime}\right), 79.1(\mathrm{CH}$, C-5'), 79.1 (CH, C-3'), $75.6\left(\mathrm{CH}, \mathrm{C}-2^{\prime}\right), 71.9\left(\mathrm{CH}, \mathrm{C}-4^{\prime}\right)$, and
$\left.63.0\left(\mathrm{CH}_{2}, \mathrm{C}-6^{\prime}\right)\right]$; (3) a fragment of $-\mathrm{CH}_{2}-\mathrm{CH}(\mathrm{O})-\mathrm{CH}_{2}-$ in ring $\mathrm{A}$ deduced from the ${ }^{1} \mathrm{H}-{ }^{1} \mathrm{H}$ COSY and $\mathrm{HSQC}$ spectra; (4) HMBC correlations of $\mathrm{H}-3 / \mathrm{C}-1^{\prime}$ and $\mathrm{H}-1^{\prime} / \mathrm{C}-3$; of $\mathrm{H}_{2}-19 /$ C-1, C-5, C-9, and C-10; of $\mathrm{H}_{2}-2 / \mathrm{C}-1, \mathrm{C}-3, \mathrm{C}-4$, and C-10; and of $\mathrm{H} \beta-4 / \mathrm{C}-2, \mathrm{C}-3, \mathrm{C}-5, \mathrm{C}-6$, and C-10. Thus, the structure of 9 (withalongolide I) was determined as $3-O-\beta$-D-glucopyranosyl19,27-dihydroxy-1-oxo-witha-5,24-dienolide.

Compound 10 was assigned a molecular formula of $\mathrm{C}_{34} \mathrm{H}_{52} \mathrm{O}_{11}$ by HRESIMS and NMR experiments. Similar to those of $\mathbf{9}$, the NMR data of $\mathbf{1 0}$ (Tables 4 and 5) displayed the presence of an oxygenated $\mathrm{C}-19$ methylene group $\left[{ }^{13} \mathrm{C}: \delta 63.9\right.$ $\mathrm{CH}_{2} ;{ }^{1} \mathrm{H}: \delta 4.32(1 \mathrm{H}, \mathrm{d}, J=11.0 \mathrm{~Hz}), 4.11(1 \mathrm{H}, \mathrm{d}, J=11.0$ $\mathrm{Hz})]$ and three methyl groups $\left[{ }^{13} \mathrm{C}: \delta 12.6,13.0,14.1 ;{ }^{1} \mathrm{H}: \delta\right.$ $0.80(\mathrm{~s}), 0.99(\mathrm{~d}, J=6.6 \mathrm{~Hz}), 2.04(\mathrm{~s})]$. The obvious differences between 10 and 9 were the presence of an oxygenated methine $(\delta 69.5)$ in 10 instead of the keto carbon $(\mathrm{C}-1, \delta 208.9)$ in 9, implying that a hydroxy group is attached to $\mathrm{C}-1$. This was supported by the presence of a ${ }^{1} \mathrm{H}-{ }^{1} \mathrm{H}$ COSY fragment of $-\mathrm{CH}(\mathrm{O})-\mathrm{CH}_{2}-\mathrm{CH}(\mathrm{O})-\mathrm{CH}_{2}-$ assigned as a $\mathrm{C}-1$ to $\mathrm{C}-4$ moiety in ring $\mathrm{A}$ and confirmed by $\mathrm{HMBC}$ correlations of $\mathrm{H}_{2}$ 19/C-1, C-5, C-9, and C-10 and of $\mathrm{H}_{2}-4 / \mathrm{C}-2$, C-3, C-5, C-6, and $\mathrm{C}-10$. The orientation of the hydroxy group at $\mathrm{C}-1$ was assigned as $\alpha$ on the basis of the small coupling constant of $\mathrm{H}-1$ $\left(\delta\right.$ 4.61, s) $/ \mathrm{H}_{2}$-2. Furthermore, it was determined that the 
glucose was attached to $\mathrm{C}-28$ by the $\mathrm{HMBC}$ correlations of $\mathrm{H}_{2}$ 28/C-23, 24, 25, $1^{\prime}$ and of $\mathrm{H}-1^{\prime} / \mathrm{C}-28$, as well as the chemical shifts of C-23 ( $\delta$ 25.2), C-24 ( $\delta$ 148.8), C-25 ( $\delta$ 125.2), C-26 $(\delta$ 167.1), C-27 ( $\delta$ 13.0), and C-28 $(\delta$ 67.1) and detailed comparison to those of withanolides with a $28-O$-glucoside moiety. ${ }^{20}$ Thus, the structure of $\mathbf{1 0}$ (withalongolide J) was determined as $28-O-\beta$-D-glucopyranosyl- $1 \alpha, 3 \beta, 19$-trihydroxywitha-5,24-dienolide.

Similar to withalongolide J (10), compounds 11-14 were shown to possess the same nine-carbon side chain with an $\alpha, \beta$ unsaturated $\delta$-lactone and a glucose moiety at C-28, on the basis of their superimposable NMR signals assigned to the side chain (Tables 4 and 5).

Saponin 11 was assigned a molecular formula of $\mathrm{C}_{33} \mathrm{H}_{46} \mathrm{O}_{10}$ by HRESIMS and NMR experiments. Excluding the six carbons corresponding to the glucose moiety, the 27-carbon aglycon implied that one carbon in the $\mathrm{C}_{28}$ withanolide scaffold must be lost. The NMR data of its aglycon were similar to those of 1,6,27-trihydroxy-19-norwitha-1,3,5(10),24-tetraenolide (a 19norwithanolide with an aromatic ring A). ${ }^{21} \mathrm{~A}$ trisubstituted aromatic ring $\mathrm{A}$ in 11 was observed from the ${ }^{1} \mathrm{H}$ NMR $(\mathrm{H}-2: \delta$ $7.14,1 \mathrm{H}, \mathrm{d}, J=7.7 \mathrm{~Hz} ; \mathrm{H}-3: \delta 7.34,1 \mathrm{H}, \mathrm{t}, J=7.7 \mathrm{~Hz}$; and $\mathrm{H}-4$ : $\delta 7.87,1 \mathrm{H}, \mathrm{d}, J=7.7 \mathrm{~Hz})$ and ${ }^{13} \mathrm{C}$ NMR $(\mathrm{C}-1: \delta 157.8 \mathrm{C}$; C-2: $\delta$ 115.1, CH; C-3: $\delta 127.4 \mathrm{CH}$; C-4: $\delta 119.3 \mathrm{CH}$; C-5: $\delta 146.2$ C; and C-10: $\delta$ 127.8, C) experiments. This was confirmed by ${ }^{1} \mathrm{H}-{ }^{1} \mathrm{H}$ COSY and HSQC experiments and HMBC correlations of $\mathrm{H}-2 / \mathrm{C}-4$ and $\mathrm{C}-10, \mathrm{H}-3 / \mathrm{C}-1$ and $\mathrm{C}-5$, and $\mathrm{H}-4 / \mathrm{C}-2$ and $\mathrm{C}-10$. Moreover, the HMBC correlations of H-4/C-6 $(\delta$ $70.7 \mathrm{CH})$, of OH-6 $(\delta 6.81, \mathrm{~d}, J=6.5 \mathrm{~Hz}) / \mathrm{C}-5$ and $\mathrm{C}-6$, and of $\mathrm{H}-7 \beta / \mathrm{C}-5$ and the ${ }^{1} \mathrm{H}-{ }^{1} \mathrm{H}$ COSY fragment $-\mathrm{CH}(\mathrm{OH})-\mathrm{CH}_{2}-$ $\mathrm{CH}-\mathrm{CH}-\mathrm{CH}_{2}-\mathrm{CH}_{2}-$ (corresponding to $-\mathrm{C}_{6}-\mathrm{C}_{7}-\mathrm{C}_{8}-\mathrm{C}_{9}-$ $\mathrm{C}_{11}-\mathrm{C}_{12}-$ ) showed that both the aglycone of 16 and $1,6,27-$ trihydroxy-19-norwitha-1,3,5(10),24-tetraenolide have the same planar structural moieties in rings $\mathrm{A}$ and $\mathrm{B}$. However, the orientation of the hydroxy group at C- 6 was assigned as $\alpha$ because of the large coupling constants $(11.0 \mathrm{~Hz})$ between $\mathrm{H}-6$ $(\delta 5.26, \mathrm{dt}, J=11.0,6.5 \mathrm{~Hz})$ and $\mathrm{H}-7 \alpha(\delta 1.63, \mathrm{q}, J=11.0 \mathrm{~Hz})$ and $(6.5 \mathrm{~Hz})$ between $\mathrm{H}-6$ and $\mathrm{H}-7 \beta(\delta 2.32$, dd, $J=11.0,6.5$ $\mathrm{Hz}$ ). Thus, the structure of $\mathbf{1 1}$ (withalongolide $\mathrm{K}$ ) was determined as 28-O- $\beta$-D-glucopyranosyl-1,6 $\alpha$-dihydroxy-19norwitha-1,3,5(10),24-tetraenolide.

Compound 12 was assigned a molecular formula of $\mathrm{C}_{33} \mathrm{H}_{48} \mathrm{O}_{11}$ by HRESIMS and NMR experiments. Its NMR data (Tables 4 and 5) were similar to those of withalongolide $\mathrm{K}$ (11), containing the same rings $\mathrm{B}, \mathrm{C}$, and $\mathrm{D}$ because of their superimposable ${ }^{1} \mathrm{H}$ and ${ }^{13} \mathrm{C}$ NMR signals. The differences observed between 12 and $\mathbf{1 1}$ were caused by changes in the ring A moiety. Unlike the aromatic ring A in 11, a conjugated 5(10)-en-1-one system in $\mathbf{1 2}$ was revealed by the chemical shifts of quaternary carbons at $\delta 199.4$ (C-1), 156.4 (C-5), and 136.5 (C-10). A ${ }^{1} \mathrm{H}-{ }^{1} \mathrm{H}$ COSY fragment of $-\mathrm{CH}_{2}-\mathrm{CH}$ $(\mathrm{OH})-\mathrm{CH}_{2}-$ was assigned as $-\mathrm{C}_{2}-\mathrm{C}_{3}-\mathrm{C}_{4}-$ in $\operatorname{ring} \mathrm{A}$ and confirmed by the HMBC correlations of $\mathrm{H}_{2}-2 / \mathrm{C}-1, \mathrm{C}-3$, and C-4 and of $\mathrm{H}_{2}-4 / \mathrm{C}-2, \mathrm{C}-5$, and C-10. Thus, the structure of 12 (withalongolide $\mathrm{L}$ ) was determined as $28-O-\beta$-D-glucopyranosyl$3 \beta, 6 \alpha$-dihydroxy-1-oxo-19-norwitha-5(10),24-dienolide.

Compound 13 was assigned a molecular formula of $\mathrm{C}_{33} \mathrm{H}_{48} \mathrm{O}_{10}$ by HRESIMS and NMR experiments. Its NMR data were similar to those observed for withalongolide $\mathrm{L}(\mathbf{1 2})$, containing a conjugated $5(10)$-en-1-one system $\left[{ }^{13} \mathrm{C}: \delta 198.3\right.$ (C-1), 153.6 (C-5), 136.1 (C-10)] in ring A. The obvious difference between 13 and 12 was the presence of a methylene $\left({ }^{13} \mathrm{C}: \delta 33.8 ;{ }^{1} \mathrm{H}: \delta 2.30,2 \mathrm{H}, \mathrm{m}\right)$ instead of an oxygenated methine $\left({ }^{13} \mathrm{C}: \delta 71.2 ;{ }^{1} \mathrm{H}: \delta 4.69\right)$, suggesting that 13 is a 6-deoxy derivative of $\mathbf{1 2}$. This observation was supported by the ${ }^{13} \mathrm{C}$ NMR high-frequency shift of C-4 ( $\delta 41.9$ in 13 and $\delta 36.9$ in 12) and C-8 ( $\delta 39.9$ in 13 and $\delta 37.5$ in 12), the lowfrequency shift of C-7 ( $\delta 26.4$ in 13 and $\delta 37.3$ in 12), and $\mathrm{HMBC}$ correlations of $\mathrm{OH}-3(\delta 6.81,1 \mathrm{H}, \mathrm{d}, J=4.1 \mathrm{~Hz}) / \mathrm{C}-2(\delta$ $49.7)$, C-3 $(\delta 66.1)$, and C-4 $(\delta 41.9)$, of $\mathrm{H}_{2}-4(\delta 2.68$, dd, $J=$ $5.9,16.8 \mathrm{~Hz}$ and $\delta 2.58$, dd, $J=2.7,16.8 \mathrm{~Hz}) / \mathrm{C}-2, \mathrm{C}-3, \mathrm{C}-5$ $(\delta$ 153.6), C-6 ( $\delta$ 33.8), and C-10 ( $\delta$ 136.1), and of $\mathrm{H}-6 \beta$ $(\delta 2.09, \mathrm{~m}) / \mathrm{C}-4, \mathrm{C}-5, \mathrm{C}-7$ ( $\delta$ 26.4), C-8 (39.9), and C-10 in 13. Thus, the structure of 13 (withalongolide $\mathrm{M}$ ) was determined as 28 -O- $\beta$-D-glucopyranosyl-3 $\beta$-hydroxy-1-oxo-19-norwitha-5(10),24-dienolide.

Compound 14 was assigned a molecular formula of $\mathrm{C}_{33} \mathrm{H}_{48} \mathrm{O}_{10}$ by HRESIMS and NMR experiments and as an isomer of withalongolide $\mathrm{M}$ (13). The NMR data of these two compounds (Tables 4 and 5) were similar to each other, having the same functional groups and the same multiplicities for all other carbons present. A conjugated 5(10)-en-6-one system $\left[{ }^{13} \mathrm{C}: \delta 198.6\right.$ (C-6), 158.7 (C-10), 130.4 (C-5)] in 14 was proposed instead of the 5(10)-en-1-one one in 13 on the basis of the following observations: (1) a ${ }^{1} \mathrm{H}-{ }^{1} \mathrm{H}$ COSY fragment of $-\mathrm{CH}_{2}-\mathrm{CH}_{2}-\mathrm{CH}(\mathrm{OH})-\mathrm{CH}_{2}-$ (from C-1 to C-4) in ring A of 14 replaced the ring A fragment $-\mathrm{CH}_{2}-\mathrm{CH}(\mathrm{OH})-\mathrm{CH}_{2}-$ (from $\mathrm{C}-2$ to $\mathrm{C}-4$ ) in 13 ; (2) a ${ }^{1} \mathrm{H}-{ }^{1} \mathrm{H}$ COSY fragment of $-\mathrm{CH}_{2}-\mathrm{CH}-\mathrm{CH}-$ (from $\mathrm{C}-7$ to $\mathrm{C}-9$ ) in ring $\mathrm{B}$ of 14 replaced the ring $\mathrm{B}$ fragment $-\mathrm{CH}_{2}-\mathrm{CH}_{2}-\mathrm{CH}-\mathrm{CH}-$ (from C-6 to C$9)$ in 13 ; $(3) \mathrm{HMBC}$ correlations of $\mathrm{H}-2 / \mathrm{C}-1(\delta 25.6), \mathrm{C}-3$ $\left(\delta\right.$ 64.7), and C-4 $\left(\delta\right.$ 32.9); of $\mathrm{H}_{2}-7 / \mathrm{C}-5$ ( $\delta$ 130.4), C-6 $(\delta$ 198.6), C-8 ( $\delta 40.0)$, and C-9 ( $\delta 46.6)$; and of H-1/C-3, C-5, and $\mathrm{C}-10(\delta$ 158.7). Furthermore, the orientation of the hydroxy group at C-3 was determined as $\alpha$ due to the small coupling constant $(J=2.2 \mathrm{~Hz})$ between $\mathrm{H}-3(\delta 4.33$, brs $) / \mathrm{H}-4 \beta$ $(\delta 2.81, \mathrm{dd}, J=2.2,15.8 \mathrm{~Hz})$ and the NOESY correlations of $\mathrm{H}-3 / \mathrm{H}-1 \beta, \mathrm{H}-2 \beta$, and $\mathrm{H}-4 \beta$. Thus, the structure of 14 (withalongolide $\mathrm{N}$ ) was assigned as $28-O-\beta$-D-glucopyranosyl$3 \alpha$-hydroxy-6-oxo-19-norwitha-5(10),24-dienolide.

Eight known compounds were identified by comparison of their data with those published in the literature, as seven withanolides, sitoindoside IX (15), ${ }^{18}$ withaferin A (16), ${ }^{1,13} 2,3$ dihydro-3 $\beta$-methoxywithaferin A $(17),{ }^{15}$ viscosalactone $\mathrm{B}$ $(18){ }^{22} 2,3$-dihydro-3 $\beta$-O-sulfate withaferin A (19), ${ }^{17} 2,3$ dihydrowithaferin A (20), ${ }^{15}$ and $3 \alpha, 6 \alpha$-epoxy- $4 \beta, 5 \beta, 27$-trihydroxy-1-oxowitha-24-enolide (21) ${ }^{23}$ and a flavonoid glucoside, rutin $(\mathbf{2 2}) .^{24}$ The full assignments of the NMR data of 15, 16, 17, 18, and 19 are listed in Tables $2-5$, as these data were either unavailable, incomplete, or in need of revision within the published literature.

The classically defined withanolide-type steroids (1-21) isolated from the title plant showed a diversity of oxygenation patterns that may be summarized as follows: (1) Six withanolides (1, 2, 4, 7, 9, and 10) have an oxygenated C-19 group, which is rare in Nature. A literature investigation showed that from the approximately 520 unmodified withanolides only nine $\mathrm{C}-19$ oxygenated withanolides have been reported so far. They are as follows: jaborosalactones $\mathrm{O},{ }^{25} \mathrm{~V}, \mathrm{~W}, \mathrm{X},{ }^{26} 46,47$, and $48,{ }^{27}$ cinerolide, ${ }^{28}$ and bracteosin $\mathrm{B}^{29}$ (2) Compounds 3 and 5 are rare examples of unmodified withanolides having an oxygenated C-11, although withasomniferanolide (with an $11 \beta$ $\mathrm{OH}$ group) ${ }^{30}$ somniferanolide (with an $11 \beta-\mathrm{OH}$ group), ${ }^{30}$ and witharifeen (with an $11 \alpha$-OH group) ${ }^{31}$ have been previously reported. (3) Saponins 10-14 have a sugar constituent attached at C-28. Only two previously published withanolide 
saponins (physagulins $\mathrm{E}$ and $\mathrm{G})^{20}$ have been shown to have a sugar moiety at C-28 thus far. (4) Compounds 11-14 are the first reported examples of C-19 norwithanolide saponins. It should be noted, however, that there are only four C-19 norwithanolides (jaborosalactones $\mathrm{Q}^{21} 7,{ }^{32}$ and $45 ; 12-\mathrm{O}$ methyljaborosalactone $45^{27}$ ) reported in the literature. (5) Most withanolides have an oxygenated $\mathrm{C}-1$ in ring A, but $\mathbf{1 5}$ is the exception by not being oxidized at $\mathrm{C}-1$. In addition, the presence of a 3-O-sulfate group in naturally occurring withanolides is extremely rare. Besides withanolides 7 and 19, there are only five other 3-O-sulfate withanolides previously reported from Datura metel, ${ }^{33}$ Solanum cilistum, ${ }^{34}$ and Withania somnifera. ${ }^{35}$

All the withanolides $(\mathbf{1 - 2 1})$ and the four acetylated derivatives (1a, $\mathbf{1} \mathbf{b}, \mathbf{2} \mathbf{a}$, and $\mathbf{2} \mathbf{b}$ ) were tested against the HNSCC (JMAR, MDA-1986), melanoma (B16F10 and SKMEL-28), and/or normal fetal fibroblast (MRC-5) cells for their cytotoxicity. As summarized in Table 6, withanolides 1-5, 7,

Table 6. Cytotoxicity $\left(\mathrm{IC}_{50}\right)$ of Isolated Withanolides $(\mu \mathrm{M})$ against Five Cell Lines ${ }^{a}$

\begin{tabular}{|c|c|c|c|c|c|}
\hline compound & $\mathrm{B} 16 \mathrm{~F} 10$ & $\begin{array}{c}\text { SKMEL- } \\
28\end{array}$ & JMAR & $\begin{array}{c}\text { MDA- } \\
1986\end{array}$ & MRC-5 \\
\hline 1 & $>10$ & 5.1 & 5.3 & 3.3 & $>10$ \\
\hline $1 \mathrm{a}$ & 0.067 & 0.54 & 0.16 & 0.91 & 0.58 \\
\hline $1 b$ & 0.098 & 0.81 & 0.14 & 2.2 & 0.41 \\
\hline 2 & 0.20 & 3.9 & 0.17 & 1.3 & 0.40 \\
\hline $2 a$ & 0.13 & 0.27 & 0.24 & 0.11 & 0.51 \\
\hline $2 b$ & 0.19 & 0.64 & 0.12 & 0.49 & 0.16 \\
\hline 3 & 0.49 & 3.0 & 0.77 & 2.6 & 3.6 \\
\hline 4 & 3.2 & 9.3 & 4.7 & $>10$ & 6.5 \\
\hline 5 & 5.6 & $>10$ & $>10$ & 8.3 & 7.3 \\
\hline 7 & 1.3 & 4.8 & 2.3 & 2.0 & 3.3 \\
\hline 8 & $>10$ & $>10$ & 8.2 & 8.1 & 8.7 \\
\hline 15 & 3.7 & 8.3 & 4.2 & $>10$ & 5.2 \\
\hline 16 & 0.29 & 4.0 & 2.0 & 0.80 & 0.20 \\
\hline 19 & 0.18 & 5.1 & 0.48 & 0.27 & 1.4 \\
\hline cisplatin (positive control) & 1.0 & 1.1 & 1.1 & 1.6 & 8.9 \\
\hline
\end{tabular}

${ }^{a}$ For cell lines used, see text. Withanolides 6, 9-14, 17, 18, 20, and 21 were inactive for all cell lines used $\left(\mathrm{IC}_{50}>10 \mu \mathrm{M}\right)$.

$8,15,16$, and 19 and the four derivatives (1a, 1b, 2a, and 2b) showed cytotoxic effects against the cells tested with $\mathrm{IC}_{50}$ values in the range $0.067-9.3 \mu \mathrm{M}$, while the other withanolides were inactive. Similar to withaferin A (16), withanolides 1-3, containing the functional groups of a 2-en-1-one in ring $A$, a $5 \beta, 6 \beta$-epoxy in ring $\mathrm{B}$, and a lactone ring in the side chain, were active, showing the importance of these three groups. The activity of the 3-O-sulfate withanolides 7 and 19 was due to their transformations to $\mathbf{1}$ and $\mathbf{1 6}$, respectively. Withanolide glycosides $\mathbf{8}$ and $\mathbf{1 5}$ displayed less cytotoxicity relative to their aglycone withaferin $\mathrm{A}$ (16). However, the esterification of the hydroxy groups at C-4, C-19, and C-27 increased the resultant cytotoxicity, as shown for the acetylated derivatives 1a and $2 \mathrm{a}$ with $\mathrm{IC}_{50}$ values less than $1 \mu \mathrm{M}$ against all the cells tested. These results are in agreement with previous structure-activity relationship reports. ${ }^{10,36,37}$ In addition, it should be noted that withalongolide A (1), withalongolide B (2), and withaferin A (16) are most likely responsible for the cytotoxic activities of the extract prepared from the title plant due to their relatively high abundance levels $(0.16 \%$ for $1,0.10 \%$ for 16 , and $0.03 \%$ for 2).

\section{EXPERIMENTAL SECTION}

General Experimental Procedures. Melting points were obtained using an MPA100 melting point apparatus. Optical rotations were measured with a Rudolph RS Autopol IV automatic polarimeter. IR data were obtained with a Thermo Nicolet Avatar 360 FT-IR spectrometer. NMR spectra were recorded with a Bruker AV-400 or AV-500 instrument with a cryoprobe for ${ }^{1} \mathrm{H}, \mathrm{APT}, \mathrm{COSY} / \mathrm{DQF}-$ COSY, HSQC, HMBC, and NOESY/ROESY. Chemical shift values are given in $\delta(\mathrm{ppm})$ using the peak signals of the solvent $\mathrm{C}_{5} \mathrm{D}_{5} \mathrm{~N}\left(\delta_{\mathrm{H}}\right.$ 8.74, 7.58, and 7.22; and $\delta_{\mathrm{C}} 150.35,135.91$, and 123.87$)$ or $\mathrm{CDCl}_{3}\left(\delta_{\mathrm{H}}\right.$ 7.24 and $\left.\delta_{\mathrm{C}} 77.23\right)$ as references, and coupling constants are reported in Hz. ESIMS data were measured with an Agilent 1200 Series LCMS/MS ion trap 6300 mass spectrometer. HRESIMS data were collected with a LCT Premier time-of-flight mass spectrometer (Waters Corp., Milford, MA, USA). Column chromatography was performed on silica gel (particle size 12-25 $\mu \mathrm{m}$ ) (Sorbent Technologies, Atlanta, GA, USA), MCI CHP20P (particle size 75$150 \mu \mathrm{m}$ ) (Sigma-Aldrich, Saint Louis, MO, USA), or Sephadex LH-20 (GE Healthcare, Piscataway, NJ, USA) or $\mathrm{C}_{18}$ reversed-phase silica gel (particle size 40-65 $\mu \mathrm{m}$ ) (Sigma-Aldrich). Normal-phase silica gel G TLC plates (w/UV 254) and reversed-phase $C_{18}$ TLC plates (w/UV 254) (Sorbent Technologies) were used for fraction detection. The spots were visualized using UV light at $254 \mathrm{~nm}$ and spraying with $10 \%$ EtOH-sulfuric acid reagent. Semipreparative HPLC was performed on an Agilent 1200 unit equipped with a DAD detector, utilizing a Lichrospher RP-18 column $(250 \times 10 \mathrm{~mm}, 5 \mu \mathrm{m})$.

Plant Material. Fresh aerial parts of the plant P. longifolia were collected from the Kanopolis wildlife area (latitude: $38.74206^{\circ}$; longitude: $97.98467^{\circ}$ ), Ellsworth County, Kansas, USA, in August 2009. It was identified by plant taxonomist Dr. Kelly Kindscher at the Kansas Biological Survey, University of Kansas. A voucher specimen (Hillary Loring 3583) was deposited in the R.L. McGregor Herbarium of the University of Kansas.

Extraction and Isolation. The collected biomass was air-dried at room temperature. The dried material was then ground to a coarse powder $(930 \mathrm{~g})$ and extracted three times with $\mathrm{CH}_{2} \mathrm{Cl}_{2}-\mathrm{MeOH}$ (50:50, $4.0 \mathrm{~L}$ ) at room temperature. After removing the solvents under vacuum, the extract $(107 \mathrm{~g})$ was suspended in $400 \mathrm{~mL}$ of $\mathrm{H}_{2} \mathrm{O}$, followed by partitions with $n$-hexane, EtOAc, and $n$-butanol $(3 \times 500 \mathrm{~mL})$. The resulting ethyl acetate fraction $(22 \mathrm{~g})$ collected was applied to silica gel flash CC (column chromatography) and eluted subsequently with hexane-acetone mixtures of increasing polarities. The fraction obtained on elution with hexane-acetone $(80: 20)(1.0 \mathrm{~g})$ was again subjected to silica gel $\mathrm{CC}$ [eluted with $\mathrm{CH}_{2} \mathrm{Cl}_{2}-\mathrm{CH}_{3} \mathrm{COCH}_{3}(90: 10)$ ] to afford compound $2(280 \mathrm{mg})$. The fraction $(3.0 \mathrm{~g})$ obtained on elution with hexane-acetone (70:30) was subjected to silica gel CC [eluted with $\left.\mathrm{CH}_{2} \mathrm{Cl}_{2}-\mathrm{CH}_{3} \mathrm{COCH}_{3}(80: 20)\right]$ to yield compounds 16 (730 mg), 17 $(7 \mathrm{mg})$, and $20(10 \mathrm{mg})$. The fraction $(700 \mathrm{mg})$ obtained on elution with hexane-acetone (65:35) was subjected further to silica gel CC [eluted with hexane-acetone (65:35)] to afford compounds $3(30 \mathrm{mg})$ and $5(5 \mathrm{mg})$. The fraction $(2.2 \mathrm{~g})$ acquired on elution with hexaneacetone $(60: 40)$ was applied to silica gel CC [eluted with hexaneacetone (60:40)] to afford compounds $1(1200 \mathrm{mg})$ and $4(15 \mathrm{mg})$. The $n$-butanol fraction $(29 \mathrm{~g})$ obtained was subjected to a MCI CHP20P gel CC $(500 \mathrm{~g})$ eluted with a mixture of $\mathrm{H}_{2} \mathrm{O}-\mathrm{MeOH}(100: 0$, $80: 20,60: 40,40: 60,85: 15,0: 100)$, in order of increasing concentrations of methanol. The $85 \% \mathrm{MeOH}$ fraction $(3.5 \mathrm{~g}$ ) was subjected to silica gel $\mathrm{CC}$, eluted with $\mathrm{CH}_{2} \mathrm{Cl}_{2}-\mathrm{CH}_{3} \mathrm{COCH}_{3}$ with increasing amounts of acetone to afford compounds 1 ( $240 \mathrm{mg}), 6$ (40 mg), 16 (200 mg), 18 $(250 \mathrm{mg})$, and $21(220 \mathrm{mg})$. The $60 \% \mathrm{MeOH}$ fraction $(4.2 \mathrm{~g})$ was subjected to silica gel $\mathrm{CC}$, eluted with $\mathrm{CH}_{2} \mathrm{Cl}_{2}-\mathrm{MeOH}-\mathrm{H}_{2} \mathrm{O}$ (7:1:0.1) with increasing amounts of $\mathrm{MeOH}-\mathrm{H}_{2} \mathrm{O}$ (10:1). Then the fractions were further subjected to reversed-phase $\mathrm{C}_{18} \mathrm{Si}$ gel column chromatography ( $200 \mathrm{~g}$, particle size $40-63 \mu \mathrm{m}$ ), eluted by $\mathrm{MeOH}-$ $\mathrm{H}_{2} \mathrm{O}$ (40:60, 50:50, 60:40, 65:35). The fractions obtained were subjected to semipreparative HPLC, with the mobile phase $\mathrm{CH}_{3} \mathrm{CN}-$ $\mathrm{H}_{2} \mathrm{O}(26: 74 ; 28: 72)$, to afford compounds 7 (40 mg), 8 (35 mg), 9 (9 $\mathrm{mg}), 10$ (12 mg), 11 (6 mg), 12 (5 mg), 13 (6 mg), 14 (7 mg), 15 (22 $\mathrm{mg}), 19(35 \mathrm{mg})$, and $22(80 \mathrm{mg})$. 
Withalongolide $A$ (1): colorless cuboid crystals $\left(\mathrm{CH}_{3} \mathrm{CN}\right)$; mp 216-217 ${ }^{\circ} \mathrm{C} ;[\alpha]^{25}{ }_{\mathrm{D}}+14.2\left(c 0.16, \mathrm{CHCl}_{3}\right)$; IR (neat) $\nu_{\max } 3431(\mathrm{br})$, 3233 (br), 2922, 1706, 1671, 1400, 1037, $962 \mathrm{~cm}^{-1}$; ${ }^{1} \mathrm{H}$ NMR and ${ }^{13} \mathrm{C}$ NMR, see Tables 1 and 2; ESIMS (positive-ion mode) $m / z 487(\mathrm{M}+$ $\mathrm{H}, 6), 469\left(\mathrm{M}-\mathrm{H}_{2} \mathrm{O}+\mathrm{H}, 100\right), 451\left(\mathrm{M}-2 \mathrm{H}_{2} \mathrm{O}+\mathrm{H}, 6\right)$; HRESIMS $m / z 509.2489[\mathrm{M}+\mathrm{Na}]^{+}\left(\right.$calcd for $\mathrm{C}_{28} \mathrm{H}_{38} \mathrm{O}_{7} \mathrm{Na}$, 509.2471), $\mathrm{m} / z$ 487.2674 $[\mathrm{M}+\mathrm{H}]^{+}$(calcd for $\mathrm{C}_{28} \mathrm{H}_{39} \mathrm{O}_{7}$, 487.2696), $m / z 469.2585\left[\mathrm{M}-\mathrm{H}_{2} \mathrm{O}+\mathrm{H}\right]^{+}$(calcd for $\mathrm{C}_{28} \mathrm{H}_{37} \mathrm{O}_{6}$, 469.2590)

Single-Crystal X-ray Structure Determination of Withalongolide $A$ (1). Crystal analysis was performed with a colorless plate crystal (dimensions $0.42 \times 0.35 \times 0.21 \mathrm{~mm}^{3}$ ) obtained from $\mathrm{CH}_{2} \mathrm{Cl}_{2}-$ $\mathrm{CH}_{3} \mathrm{CN}(1: 1)$ using Mo $\mathrm{K} \alpha$ radiation $(\lambda=0.71073 \AA)$ on a Bruker SMART APEX diffractometer equipped with a sealed-tube $\mathrm{X}$-ray source and a graphite monochromator. Crystal data for $\mathbf{1}: \mathrm{C}_{28} \mathrm{H}_{38} \mathrm{O}_{7}$ (formula weight 486.58), monoclinic, space group $P 2_{1}, T=100(2) \mathrm{K}$, crystal cell parameters $a=8.370(2) \AA, b=10.523(3) \AA, c=14.280(3)$ $\AA, \beta=104.552(4)^{\circ}, V=1217.4(5) \AA^{3}, D_{\mathrm{c}}=1.327 \mathrm{Mg} / \mathrm{m}^{3}, Z=2$, $F(000)=524$, absorption coefficient $\mu=0.094 \mathrm{~mm}^{-1}$. A total of 11 335 reflections were collected in the range $2.43^{\circ}<\theta<29.21^{\circ}$, with 5809 independent reflections $\left[R_{(\mathrm{int})}=0.050\right]$ and 5478 with $I>2 \sigma(I)$; completeness to $\theta_{\max }$ was $93.1 \%$. Multiscan absorption correction applied; full-matrix least-squares refinement on $F^{2}$, the numbers of data/restraints/parameters were 5809/1/468; goodness-of-fit on $F^{2}=$ 1.015; final $R$ indices $[I>2 \sigma(I)], R_{1}=0.045, w R_{2}=0.098 ; R$ indices (all data), $R_{1}=0.048, w R_{2}=0.099$; largest difference peak and hole, 0.37 and $-0.21 \mathrm{e} / \AA^{-3}$.

Acetylation of Withalongolide A (1). A solution of 1 (50 mg) in pyridine $(8 \mathrm{~mL})$ and acetic anhydride $(2 \mathrm{~mL})$ was stirred for $24 \mathrm{~h}$ at room temperature. Then $50 \mathrm{~mL}$ of water was added to the solution. The precipitate $(70 \mathrm{mg})$ was subjected to semipreparative HPLC, eluted with the mobile phase $\mathrm{CH}_{3} \mathrm{CN}-\mathrm{H}_{2} \mathrm{O}$ (45:55), to afford triacetate $1 \mathbf{a}(40 \mathrm{mg})$ and diacetate $\mathbf{1 b}(10 \mathrm{mg})$.

Withalongolide A 4,19,27-triacetae (1a): IR (neat) $\nu_{\max } 2953$ (br), 1731, 1702, 1674, 1366, 1208, 1023, $966 \mathrm{~cm}^{-1}$; ${ }^{1} \mathrm{H}$ NMR and ${ }^{13} \mathrm{C}$ NMR, see Tables 1 and 2; ESIMS (positive-ion mode) $m / z 630(\mathrm{M}+$ $\left.\mathrm{H}_{2} \mathrm{O}, 30\right), 613(\mathrm{M}+\mathrm{H}, 100) ;$ HRESIMS $m / z 635.2829[\mathrm{M}+\mathrm{Na}]^{+}$ (calcd for $\mathrm{C}_{34} \mathrm{H}_{44} \mathrm{O}_{10} \mathrm{Na}, 635.2832$ ).

Withalongolide A 4,27-diacetae (1b): IR (neat) $\nu_{\max } 3536$ (br), 2922, 1736, 1701, 1674, 1376, 1215, 1021, $967 \mathrm{~cm}^{-1} ;{ }^{1} \mathrm{H}$ NMR and ${ }^{13} \mathrm{C}$ NMR, see Tables 1 and 2; ESIMS (positive-ion mode) $\mathrm{m} / z 1163$ $(2 \mathrm{M}+\mathrm{Na}, 6), 588\left(\mathrm{M}+\mathrm{H}_{2} \mathrm{O}, 10\right), 571(\mathrm{M}+\mathrm{H}, 100) ;$ HRESIMS $m / z$ 593.2740 $[\mathrm{M}+\mathrm{Na}]^{+}$(calcd for $\mathrm{C}_{32} \mathrm{H}_{42} \mathrm{O}_{7} \mathrm{Na}$, 593.2727).

Withalongolide $B(2)$ : colorless plate crystals (toluene); mp 197$198{ }^{\circ} \mathrm{C} ;[\alpha]^{25}{ }_{\mathrm{D}}+12.3\left(\mathrm{c} \mathrm{0.15}, \mathrm{CHCl}_{3}\right)$; IR (neat) $\nu_{\max } 3260$ (br), 3006, 2946, 2887, 1693, 706, 1675, 1383, 1082, $763 \mathrm{~cm}^{-1}$; ${ }^{1} \mathrm{H}$ NMR and ${ }^{13} \mathrm{C}$ NMR, see Tables 1 and 2; ESIMS (positive-ion mode) $\mathrm{m} / z 963$ $(2 \mathrm{M}+\mathrm{Na}, 40), 941(2 \mathrm{M}+\mathrm{H}, 70), 493(\mathrm{M}+\mathrm{Na}, 10), 471(\mathrm{M}+\mathrm{H}, 4)$, $453\left(\mathrm{M}-\mathrm{H}_{2} \mathrm{O}+\mathrm{H}, 100\right), 435\left(\mathrm{M}-2 \mathrm{H}_{2} \mathrm{O}+\mathrm{H}, 45 \%\right)$; HRESIMS $m / z 493.2554[\mathrm{M}+\mathrm{Na}]^{+}$(calcd for $\mathrm{C}_{28} \mathrm{H}_{38} \mathrm{O}_{6} \mathrm{Na}, 493.2566$ ).

Single-Crystal X-ray Structure Determination of Withalongolide $B$ (2). Crystal analysis was performed with a colorless plate (dimensions $0.21 \times 0.16 \times 0.15 \mathrm{~mm}^{3}$ ) obtained from $\mathrm{CH}_{2} \mathrm{Cl}_{2}-$ $\mathrm{CH}_{3} \mathrm{COCH}_{3}$-toluene $(1: 1: 1)$ using $\mathrm{Cu} \mathrm{K} \alpha$ radiation $(\lambda=1.54178 \AA)$ on a Bruker APEX2 diffractometer equipped with a Bruker MicroStar microfocus rotating anode $\mathrm{X}$-ray source and Helios multilayer optics. Crystal data for 2: $\mathrm{C}_{28} \mathrm{H}_{38} \mathrm{O}_{6} \cdot \mathrm{C}_{7} \mathrm{H}_{8}$ (formula weight 562.72), orthorhombic, space group $P 2_{1} 2_{1} 2_{1}, T=100(2) \mathrm{K}$, crystal cell parameters $a=7.1844(3) \AA, b=26.0678(10) \AA, c=49.0852(18) \AA$, $V=9192.8(6) \AA^{3}, D_{c}=1.220 \mathrm{Mg} / \mathrm{m}^{3}, Z=12, F(000)=3648$, absorption coefficient $\mu=0.65 \mathrm{~mm}^{-1}$. A total of 32032 reflections were collected in the range $1.80^{\circ}<\theta<69.15^{\circ}$, with 13806 independent reflections $\left[R_{\text {(int) }}=0.035\right]$ and 12653 with $I>2 \sigma(I)$; completeness to $\theta_{\max }$ was $90.8 \%$. Multiscan absorption correction applied; full-matrix least-squares refinement on $F^{2}$, the numbers of data/restraints/parameters were 13 806/0/1108; goodness-of-fit on $F^{2}=1.083$; final $R$ indices $[I>2 \sigma(I)]$, $R_{1}=0.096, w R_{2}=0.233 ; R$ indices (all data), $R_{1}=0.102, w R_{2}=0.238$; largest difference peak and hole, 0.84 and $-0.32 \mathrm{e} / \AA^{-3}$.

Acetylation of Withalongolide B (2). A solution of $2(50 \mathrm{mg})$ in pyridine $(8 \mathrm{~mL})$ and acetic anhydride $(2 \mathrm{~mL})$ was stirred for $24 \mathrm{~h}$ at room temperature. Then $50 \mathrm{~mL}$ of water was added to the solution. The precipitate $(65 \mathrm{mg})$ was subjected to semipreparative HPLC, eluted with the mobile phase $\mathrm{CH}_{3} \mathrm{CN}-\mathrm{H}_{2} \mathrm{O}$ (43:57), to afford diacetate $2 \mathbf{a}(41 \mathrm{mg})$ and monoacetate $2 \mathbf{b}(11 \mathrm{mg})$.

Withalongolide B 4,19-diacetate (2a): IR (neat) $\nu_{\max } 2943$ (br) $1738,1698,1368,1220,1127,1043,1019,762 \mathrm{~cm}^{-1} ;{ }^{1} \mathrm{H}$ NMR and ${ }^{13} \mathrm{C}$ NMR, see Tables 1 and 2; ESIMS (positive-ion mode) $\mathrm{m} / \mathrm{z} 1109$ $(2 \mathrm{M}+\mathrm{H}, 60), 577(\mathrm{M}+\mathrm{Na}, 40), 555(\mathrm{M}+\mathrm{H}, 30), 495(\mathrm{M}-$ $\mathrm{HOAC}+\mathrm{H}, 100), 435(\mathrm{M}-2 \mathrm{HOAC}+\mathrm{H}, 30), 296$ (70); HRESIMS $m / z 577.2764[\mathrm{M}+\mathrm{Na}]^{+}$(calcd for $\left.\mathrm{C}_{32} \mathrm{H}_{42} \mathrm{O}_{8} \mathrm{Na}, 577.2727\right)$.

Withalongolide B 4-acetate (2b): IR (neat) $\nu_{\max } 3536$ (br), 2922, 1736, 1701, 1674, 1376, 1215, 1021, $967 \mathrm{~cm}^{-1} ;{ }^{1} \mathrm{H}$ NMR and ${ }^{13} \mathrm{C}$ NMR, see Tables 1 and 2; ESIMS (positive-ion mode) $\mathrm{m} / z 1047$ $(2 \mathrm{M}+\mathrm{Na}, 30), 1025(2 \mathrm{M}+\mathrm{H}, 75), 513(\mathrm{M}+\mathrm{H}, 100), 453(\mathrm{M}-$ HOAc $+\mathrm{H}, 6$ ); HRESIMS $\mathrm{m} / z$ 535.2670 $[\mathrm{M}+\mathrm{Na}]^{+}$(calcd for $\mathrm{C}_{30} \mathrm{H}_{40} \mathrm{O}_{7} \mathrm{Na}, 535.2672$ ).

Withalongolide $\mathrm{C}$ (3): colorless cuboid crystals, $\mathrm{mp} 197-198{ }^{\circ} \mathrm{C}$; $[\alpha]_{\mathrm{D}}^{25}+10.3\left(c 0.12, \mathrm{CHCl}_{3}\right.$ ); IR (neat) $\nu_{\max } 3550$ (br), 3419 (br), 2952, 2879, 1686, 1663,1394, 1227, 1026, $957 \mathrm{~cm}^{-1}$; ${ }^{1} \mathrm{H}$ NMR and ${ }^{13} \mathrm{C}$ NMR, see Tables 1 and 2; ESIMS (positive-ion mode) $\mathrm{m} / z 469$ $\left(\mathrm{M}-\mathrm{H}_{2} \mathrm{O}+\mathrm{H}, 100\right)$; HRESIMS $m / z 509.2481[\mathrm{M}+\mathrm{Na}]^{+}$(calcd for $\mathrm{C}_{28} \mathrm{H}_{38} \mathrm{O}_{7} \mathrm{Na}$, 509.2471).

Single-Crystal X-ray Structure Determination of Withalongolide $C$ (3). Crystal analysis was performed with a colorless irregular chunk (dimensions $0.45 \times 0.32 \times 0.25 \mathrm{~mm}^{3}$ ) obtained from $\mathrm{CH}_{2} \mathrm{Cl}_{2}-$ $\mathrm{CH}_{3} \mathrm{CN}(1: 1)$ and measured using Mo K $\alpha$ radiation $(\lambda=0.71073 \AA)$ on a Bruker APEX diffractometer equipped with a sealed-tube X-ray source and a graphite monochromator. Crystal data for 3: $\mathrm{C}_{28} \mathrm{H}_{38} \mathrm{O}_{7}$ (formula weight 486.58), orthorhombic, space group $P 2_{1} 2_{1} 2_{1}, T=$ $100(2) \mathrm{K}$, crystal cell parameters $a=10.679(4) \AA, b=12.245(5) \AA, c=$ 18.674(7) $\AA, V=2442(2) \AA^{3}, D_{c}=1.324 \mathrm{Mg} / \mathrm{m}^{3}, Z=4, F(000)=$ 1048 , absorption coefficient $\mu=0.094 \mathrm{~mm}^{-1}$. A total of 22352 reflections were collected in the range $2.53^{\circ}<\theta<29.12^{\circ}$, with 6145 independent reflections $\left[R_{(\mathrm{int})}=0.055\right]$ and 5925 with $I>2 \sigma(I)$; completeness to $\theta_{\max }$ was $95.6 \%$. Multiscan absorption correction applied; full-matrix least-squares refinement on $F^{2}$, the numbers of data/restraints/parameters were 6145/0/468; goodness-of-fit on $F^{2}=$ 1.080; final $R$ indices $[I>2 \sigma(I)], R_{1}=0.045, w R_{2}=0.109 ; R$ indices (all data), $R_{1}=0.046, w R_{2}=0.113$; largest difference peak and hole, 0.63 and $-0.21 \mathrm{e} / \AA^{-3}$.

Withalongolide $D(4)$ : $[\alpha]_{\mathrm{D}}^{25}+2.7\left(c 0.08, \mathrm{CHCl}_{3}\right)$; IR (neat) $\nu_{\max }$ 3411 (br), 2944 (br), 1693, 1393, 1211, $1023 \mathrm{~cm}^{-1}$; ${ }^{1} \mathrm{H}$ NMR and ${ }^{13} \mathrm{C}$ NMR, see Tables 2 and 3; ESIMS (positive-ion mode) $\mathrm{m} / z 1059$ $(2 \mathrm{M}+\mathrm{Na}, 6), 519(\mathrm{M}+\mathrm{H}, 25), 501\left(\mathrm{M}-\mathrm{H}_{2} \mathrm{O}+\mathrm{H}, 100\right), 483(\mathrm{M}-$ $2 \mathrm{H}_{2} \mathrm{O}+\mathrm{H}, 4$ ); HRESIMS $\mathrm{m} / z 541.2798[\mathrm{M}+\mathrm{Na}]^{+}$(calcd for $\left.\mathrm{C}_{28} \mathrm{H}_{38} \mathrm{O}_{7} \mathrm{Na}, 541.2777\right)$.

Withalongolide $E$ (5): $[\alpha]_{\mathrm{D}}^{25}+2.2\left(c 0.12, \mathrm{CHCl}_{3}\right)$; IR (neat) $\nu_{\max }$ 3550 (br), 2940 (br), 1690, 1390, 1200, $1020 \mathrm{~cm}^{-1}$; ${ }^{1} \mathrm{H}$ NMR and ${ }^{13} \mathrm{C}$ NMR, see Tables 2 and 3; ESIMS (positive-ion mode) $\mathrm{m} / z 1059$ $(2 \mathrm{M}+\mathrm{Na}, 20), 541(\mathrm{M}+\mathrm{Na}, 18), 501\left(\mathrm{M}-\mathrm{H}_{2} \mathrm{O}+\mathrm{H}, 100\right)$; HRESIMS $m / z 541.2777[\mathrm{M}+\mathrm{Na}]^{+}$(calcd for $\mathrm{C}_{28} \mathrm{H}_{38} \mathrm{O}_{7} \mathrm{Na}, 541.2777$ ).

Withalongolide $F$ (6): colorless cuboid crystals, mp 190-191 ${ }^{\circ} \mathrm{C}$; $[\alpha]^{25}+8.9\left(c 0.16, \mathrm{CHCl}_{3}\right)$; IR (neat) $\nu_{\max } 2887,1683,1659,1393$, $1002,851 \mathrm{~cm}^{-1} ;{ }^{1} \mathrm{H}$ NMR and ${ }^{13} \mathrm{C}$ NMR, see Tables 2 and 3; ESIMS (positive-ion mode) $\mathrm{m} / z 871(2 \mathrm{M}+\mathrm{Na}, 25), 425(\mathrm{M}+\mathrm{H}, 100)$; HRESIMS $m / z$ 447.2503 $[\mathrm{M}+\mathrm{Na}]^{+}$(calcd for $\mathrm{C}_{27} \mathrm{H}_{38} \mathrm{O}_{4} \mathrm{Na}$, 447.2511).

Single-Crystal X-ray Structure Determination of Withalongolide $F$ (6). Crystal analysis was performed with a colorless rectangular parallelepiped (dimensions $0.39 \times 0.37 \times 0.20 \mathrm{~mm}^{3}$ ) obtained from $\mathrm{CH}_{2} \mathrm{Cl}_{2}-\mathrm{CH}_{3} \mathrm{CN}$ (1:1) and measured using Mo $\mathrm{K} \alpha$ radiation $(\lambda=$ $0.71073 \AA$ ) on a Bruker APEX diffractometer equipped with a sealedtube X-ray source and graphite monochromator. Crystal data for 6: $\mathrm{C}_{27} \mathrm{H}_{36} \mathrm{O}_{4}$ (formula weight 424.56 ), monoclinic, space group $P 2_{1}, T=$ $100(2) \mathrm{K}$, crystal cell parameters $a=10.873(5) \AA, b=9.233(4) \AA$, $c=$ $12.271(6) \AA, \beta=113.273(7)^{\circ}, V=1132(9) \AA^{3}, D_{c}=1.246 \mathrm{Mg} / \mathrm{m}^{3}$, $Z=2, F(000)=460$, absorption coefficient $\mu=0.082 \mathrm{~mm}^{-1}$. A total of 10347 reflections were collected in the range $2.85^{\circ}<\theta<29.06^{\circ}$, with 5283 independent reflections $\left[R_{(\mathrm{int})}=0.041\right]$ and 5133 with $I>2 \sigma(I)$; completeness to $\theta_{\max }$ was $93.8 \%$. Multiscan absorption correction 
applied; full-matrix least-squares refinement on $F^{2}$, the numbers of data/restraints/parameters were 5283/1/424; goodness-of-fit on $F^{2}=$ 1.055; final $R$ indices $[I>2 \sigma(I)], R_{1}=0.045, w R_{2}=0.107$; $R$ indices (all data), $R_{1}=0.046, w R_{2}=0.108$; largest difference peak and hole, 0.43 and $-0.21 \mathrm{e} / \AA^{-3}$.

Withalongolide $G$ (7): $[\alpha]^{25}-2.3(c 0.11, \mathrm{MeOH})$; IR (neat) $\nu_{\max }$ 3385 (br), 2950 (br), 1686, 1399, 1234, $992 \mathrm{~cm}^{-1}$; ${ }^{1} \mathrm{H}$ NMR and ${ }^{13} \mathrm{C}$ NMR, see Tables 2 and 3; ESIMS (positive-ion mode) $\mathrm{m} / z$ 1031 [2 $\left.\left(\mathrm{M}-\mathrm{SO}_{3}\right)+\mathrm{Na}, 20\right], 585(\mathrm{M}+\mathrm{H}, 50), 505\left(\mathrm{M}-\mathrm{SO}_{3}+\mathrm{H}, 100\right)$; (negative-ion mode) $\mathrm{m} / \mathrm{z} 583(\mathrm{M}-\mathrm{H}, 100)$; HRESIMS $\mathrm{m} / \mathrm{z}$ $607.2169[\mathrm{M}+\mathrm{Na}]^{+}$(calcd for $\left.\mathrm{C}_{28} \mathrm{H}_{40} \mathrm{O}_{11} \mathrm{SNa}, 607.2189\right)$.

Withalongolide $H$ (8): $[\alpha]^{25}-0.9(c 0.12, \mathrm{MeOH})$; IR (neat) $\nu_{\max }$ 3369 (br), 2929 (br), 1686, 1398, 1018, $916 \mathrm{~cm}^{-1}$; ${ }^{1} \mathrm{H}$ NMR and ${ }^{13} \mathrm{C}$ NMR, see Tables 4 and 5; ESIMS (positive-ion mode) $\mathrm{m} / z 796[\mathrm{M}+$ $\left.\mathrm{H}_{2} \mathrm{O}, 40\right], 471$ ( $\left.\mathrm{M}-\mathrm{rha}-\mathrm{glc}+\mathrm{H}, 100\right)$; LC-MS/MS fragments of $m / z 796$ peak: $m / z 471(\mathrm{M}-$ rha-glc $+\mathrm{H}, 100), 281$ (10); LC-MS/ MS fragments of $\mathrm{m} / \mathrm{z} 471$ peak: $\mathrm{m} / \mathrm{z} 281$ (100); HRESIMS $\mathrm{m} / \mathrm{z}$ $801.3683[\mathrm{M}+\mathrm{Na}]^{+}$(calcd for $\left.\mathrm{C}_{40} \mathrm{H}_{58} \mathrm{O}_{15} \mathrm{Na}, 801.3673\right)$.

Withalongolide I (9): $[\alpha]^{25}-7.1(c 0.08, \mathrm{MeOH}) ; \mathrm{IR}$ (neat) $\nu_{\max }$ 3381 (br), 2921 (br), 1686, 1398, $1007 \mathrm{~cm}^{-1} ;{ }^{1} \mathrm{H}$ NMR and ${ }^{13} \mathrm{C}$ NMR, see Tables 4 and 5; ESIMS (positive-ion mode) $m / z 652(\mathrm{M}+$ $\left.\mathrm{H}_{2} \mathrm{O}, 6\right), 635(\mathrm{M}+\mathrm{H}, 5), 473(\mathrm{M}-\mathrm{glc}+\mathrm{H}, 100)$; HRESIMS $m / z$ $657.3267[\mathrm{M}+\mathrm{Na}]^{+}\left(\right.$calcd for $\left.\mathrm{C}_{34} \mathrm{H}_{50} \mathrm{O}_{11} \mathrm{Na}, 657.3251\right)$.

Withalongolide J (10): $[\alpha]_{\mathrm{D}}^{25}-1.0$ (c $\left.0.13, \mathrm{MeOH}\right)$; IR (neat) $\nu_{\max } 3370$ (br), 2931 (br), 1687, 1396, 1017 (br) cm ${ }^{-1} ;{ }^{1} \mathrm{H}$ NMR and ${ }^{13} \mathrm{C}$ NMR, see Tables 4 and 5; ESIMS (positive-ion mode) $\mathrm{m} / \mathrm{z} 1273$ $(2 \mathrm{M}+\mathrm{H}, 100), 619\left(\mathrm{M}-\mathrm{H}_{2} \mathrm{O}+\mathrm{H}, 20\right), 601\left(\mathrm{M}-2 \mathrm{H}_{2} \mathrm{O}+\mathrm{H}, 15\right)$, $583\left(\mathrm{M}-3 \mathrm{H}_{2} \mathrm{O}+\mathrm{H}, 10\right), 475(\mathrm{M}-\mathrm{glc}+\mathrm{H}, 6)$; HRESIMS $\mathrm{m} / \mathrm{z}$ $659.3411[\mathrm{M}+\mathrm{Na}]^{+}\left(\right.$calcd for $\left.\mathrm{C}_{34} \mathrm{H}_{52} \mathrm{O}_{11} \mathrm{Na}, 657.3407\right)$.

Withalongolide $K$ (11): $[\alpha]^{25}{ }_{\mathrm{D}}+3.1$ (c $\left.0.17, \mathrm{MeOH}\right)$; IR (neat) $\nu_{\max } 3381$ (br), 2921 (br), 1686, 1398, $1007 \mathrm{~cm}^{-1}$; ${ }^{1} \mathrm{H}$ NMR and ${ }^{13} \mathrm{C}$ NMR, see Tables 4 and 5; ESIMS (positive-ion mode) $\mathrm{m} / z 460(\mathrm{M}-$ glc $+\mathrm{H}, 40) 603(\mathrm{M}+\mathrm{H}, 35), 1205(2 \mathrm{M}+\mathrm{H}, 100) ;$ HRESIMS $m / z$ $625.33007[\mathrm{M}+\mathrm{Na}]^{+}$(calcd for $\left.\mathrm{C}_{33} \mathrm{H}_{46} \mathrm{O}_{10} \mathrm{Na}, 625.2989\right)$.

Withalongolide L (12): $[\alpha]^{25}-3.1(c 0.09, \mathrm{MeOH})$; IR (neat) $\nu_{\max } 3350$ (br), 2931 (br), 1687, 1396, $1018 \mathrm{~cm}^{-1}$; ${ }^{1} \mathrm{H}$ NMR and ${ }^{13} \mathrm{C}$ NMR, see Tables 4 and 5; ESIMS (positive-ion mode) $\mathrm{m} / z 1241$ $(2 \mathrm{M}+\mathrm{H}, 15), 1079(2 \mathrm{M}-$ glc $+\mathrm{H}, 30), 638\left(\mathrm{M}+\mathrm{H}_{2} \mathrm{O}, 80\right) .459$ $(\mathrm{M}-\mathrm{glc}+\mathrm{H}, 100)$; LC-MS/MS fragments of the $\mathrm{m} / z 638$ peak: $\mathrm{m} / \mathrm{z}$ $621(\mathrm{M}+\mathrm{H}, 80), 459(\mathrm{M}-\mathrm{glc}+\mathrm{H}, 100)$; HRESIMS $m / z 643.3101$ $[\mathrm{M}+\mathrm{Na}]^{+}$(calcd for $\left.\mathrm{C}_{33} \mathrm{H}_{48} \mathrm{O}_{11} \mathrm{Na}, 643.3094\right)$.

Withalongolide $M$ (13): $[\alpha]_{\mathrm{D}}^{25}-4.4(c 0.08, \mathrm{MeOH})$; IR (neat) $\nu_{\max } 3380$ (br), 2932 (br), 1687, 1650, 1388, $1070 \mathrm{~cm}^{-1}$; ${ }^{1} \mathrm{H}$ NMR and ${ }^{13} \mathrm{C}$ NMR, see Tables 4 and 5; ESIMS (positive-ion mode) $\mathrm{m} / \mathrm{z} 1209$ $(2 \mathrm{M}+\mathrm{H}, 20), 1048(2 \mathrm{M}-$ glc $+\mathrm{H}, 30), 622\left(\mathrm{M}+\mathrm{H}_{2} \mathrm{O}, 30\right), 605$ $(\mathrm{M}+\mathrm{H}, 10), 443(\mathrm{M}-\mathrm{glc}+\mathrm{H}, 100) ;$ HRESIMS $m / z 627.3156[\mathrm{M}+$ $\mathrm{Na}]^{+}$(calcd for $\left.\mathrm{C}_{33} \mathrm{H}_{48} \mathrm{O}_{10} \mathrm{Na}, 627.3145\right)$.

Withalongolide N (14): $[\alpha]^{25}{ }_{\mathrm{D}}-2.0($ c $0.14, \mathrm{MeOH})$; IR (neat) $\nu_{\max } 3368$ (br), 2931 (br), 1688, 1650, 1384, 1072, $1017 \mathrm{~cm}^{-1} ;{ }^{1} \mathrm{H}$ NMR and ${ }^{13} \mathrm{C}$ NMR, see Tables 4 and 5; ESIMS (positive-ion mode) $m / z 1209(2 \mathrm{M}+\mathrm{H}, 35), 605(\mathrm{M}+\mathrm{H}, 100)$; LC-MS/MS fragments of $m / z 1209$ peak: $m / z 605(\mathrm{M}+\mathrm{H}, 100), 443(\mathrm{M}-$ glc $+\mathrm{H}, 100)$; LCMS/MS fragments of $m / z 605$ peak: $m / z 443(\mathrm{M}-$ glc $+\mathrm{H}, 100)$; HRESIMS $m / z$ 627.3146 $[\mathrm{M}+\mathrm{Na}]^{+}$(calcd for $\mathrm{C}_{33} \mathrm{H}_{48} \mathrm{O}_{10} \mathrm{Na}$, 627.3145).

Cytotoxicity Bioassay. The cytotoxicity assays were performed as previously described. ${ }^{11}$ In general, five concentrations ranging from 0.1 to $100 \mu \mathrm{g} / \mathrm{mL}$ were tested for the extracts, and 10 concentrations ranging from $50 \mathrm{nM}$ to $20 \mu \mathrm{M}$ were tested for pure compounds. Statistical analysis was carried out by one-way ANOVA on ranks test using GraphPad Prism 5 (GraphPad Software, San Diego, CA, USA). $\mathrm{IC}_{50}$ values were obtained from cell viability plots fitted with a sigmoidal dose-response function with variable slope using GraphPad Prism 5 software.

\section{ASSOCIATED CONTENT}

\section{S Supporting Information}

${ }^{1} \mathrm{H}$ and ${ }^{13} \mathrm{C}$ NMR spectra of withanolides 1-21 and the bioassay data of the samples $\left(\mathrm{CH}_{2} \mathrm{Cl}_{2}-\mathrm{MeOH}\right.$ crude extract, hexane-soluble fraction, EtOAc-soluble fraction, and $n$-BuOHsoluble fraction) are available free of charge via the Internet at http://pubs.acs.org. Crystallographic data for the structures of 1, 2, 3, and 6 reported in this paper have been deposited with the Cambridge Crystallographic Data Centre, under reference numbers CCDC 840311, CCDC 840312, CCDC 840313, and CCDC 840314, respectively. Copies of the data can be obtained, free of charge, on application to the Director, CCDC, 12 Union Road, Cambridge CB2 1EZ, UK (fax: +44(0)1223-336033 or e-mail: deposit@ccdc.cam.ac.uk).

\section{AUTHOR INFORMATION}

\section{Corresponding Author}

*Tel: +01-785-864-4844. Fax: +01-785-864-5326. E-mail: btimmer@ku.edu.

\section{ACKNOWLEDGMENTS}

This study was supported, in part, by grant IND 0061464 (awarded to B.N.T. and K.K.) from the Kansas Bioscience Authority (KBA) and Center for Heartland Plant Innovations (HPI). The authors also acknowledge partial financial assistance from grant NFP0066367 from the Institute for Advancing Medical Innovation (IAMI) (awarded to M.S.C. and to B.N.T.). Partial support of the in vitro experiments was provided by the University of Kansas Center for Cancer Experimental Therapeutics NIH-COBRE P20 RR015563 (PI: B.N.T., project award PI: M.S.C.). The authors are grateful for NSF grant CHE-0923449, which was used to purchase the new Bruker APEX2 X-ray diffractometer. The authors thank Q. Long, H. Loring, and M. Ferreira, botanists at the University of Kansas or at the Kansas Biological Survey at the University of Kansas, for assistance in plant collections and identifications.

\section{REFERENCES}

(1) Lavie, D.; Glotter, E.; Shvo, Y. J. Org. Chem. 1965, 30, 17741778.

(2) Misico, R. I.; Nicotra, V. E.; Oberti, J. C.; Barboza, G.; Gil, R. R.; Burton, G. Prog. Chem. Org. Nat. Prod. 2011, 94, 127-229.

(3) Chen, L. X.; Hao, H.; Qiu, F. Nat. Prod. Rep. 2011, 28, 705-740.

(4) Eich, E. Solanaceae and Convolvulaceae: Secondary Metabolites; Springer-Verlag: Berlin, 2008; pp 466-483.

(5) Veleiro, A. S.; Oberti, J. C.; Burton, G. In Studies in Natural Products Chemistry; Atta-ur-Rahman., Ed.; Elsevier Science, B.V.: Amsterdam, 2005; Vol. 32, pp 1019-1051.

(6) Budhiraja, R. D.; Krishan, P.; Sudhir, S. J. Sci. Ind. Res. 2000, 59, 904-911.

(7) Anjaneyulu, A. S. R.; Rao, D. S.; Lequesne, P. W. In Studies in Natural Products Chemistry; Atta-ur-Rahman., Ed.; Elsevier Science, B.V.: Amsterdam, 1998; Vol. 20, pp 135-261.

(8) Ray, A. B.; Gupta, M. Prog. Chem. Org. Nat. Prod. 1994, 63, $1-106$.

(9) Glotter, E. Nat. Prod. Rep. 1991, 415-440.

(10) Yoshida, M.; Hoshi, A.; Kuretani, K.; Ishiguro, M.; Ikekawa, N. J. Pharm. Dyn. 1979, 2, 92-97.

(11) Samadi, A. K.; Tong, X. Q.; Mukerji, R.; Zhang, H. P.; Timmermann, B. N.; Cohen, M. S. J. Nat. Prod. 2010, 73, 1476-1481.

(12) Tong, X. Q.; Zhang, H. P.; Timmermann, B. N. Phytochem. Lett. 2011 (in press) doi: 10.1016/j.phytol.2011.04.016.

(13) Fuska, J.; Prousek, J.; Rosazza, J.; Budesinsky, M. Steroids 1982, 40, 157-170.

(14) Pramanick, S.; Roy, A.; Ghosh, S.; Majumder, H. K.; Mukhopadhyay, S. Planta Med. 2008, 74, 1745-1748.

(15) Pelletier, S. W.; Mody, N. V.; Nowacki, J.; Bhattacharyya, J. J. Nat. Prod. 1979, 42, 512-521. 
(16) Lavie, D.; Kashman, Y.; Glotter, E.; Danieli, N. J. Chem. Soc. (C)

1966, 1757-1764.

(17) Xu, Y. M.; Marron, M. T.; Seddon, E.; McLaughlin, S. P.; Ray,

D. T.; Whitesell, L.; Gunatilaka, A. A. L. Bioorg. Med. Chem. 2009, 17, 2210-2214.

(18) Ghosal, S.; Kaur, R.; Srivastava, R. S. Indian J. Nat. Prod. 1988, 4, $12-13$.

(19) Ahmad, S.; Yasmmin, R.; Malik, A. Chem. Pharm. Bull. 1999, 47, 477-480.

(20) Shingu, K.; Yahara, S.; Okabe, H.; Nohara, T. Chem. Pharm. Bull. 1992, 40, 2448-2451.

(21) Veleiro, A. S.; Trocca, C. E.; Burton, G.; Oberti, J. C. Phytochemistry 1992, 31, 2550-2551.

(22) Pelletier, S. W.; Gebeyehu, G.; Nowacki, J.; Mody, N. V. Heterocycles 1981, 15, 317-320.

(23) Zhao, J.; Nakamura, N.; Hattori, M.; Kuboyama, T.; Tohda, C.; Komatsu, K. Chem. Pharm. Bull. 2002, 50, 760-765.

(24) Li, L.; Henry, G. E.; Seeram, N. P. J. Agric. Food Chem. 2009, 57, $7282-7287$

(25) Monteagudo, E. S.; Burton, G.; Gros, E. G.; Gonzalez, C. M.; Oberti, J. C. Phytochemistry 1989, 28, 2514-2515.

(26) Misico, R. I.; Oberti, J. C.; Veleiro, A. S.; Burton, G. J. Nat. Prod. 1996, 59, 66-68.

(27) Cirigliano, A. M.; Veleiro, A. S.; Misico, R. I.; Tettamanzi, M. G.; Oberti, J. C.; Burton, G. J. Nat. Prod. 2007, 70, 1644-1646.

(28) Maldonado, E.; Alvarado, V. E.; Torres, F. R.; Martínez, M.; Pérez-Castorena, A. L. Planta Med. 2005, 71, 548-553.

(29) Riaz, N.; Malik, A.; Azia-ur-Rehman.; Nawaz, S. A.; Muhammad, P.; Choudhary, M. I. Chem. Biodiversity 2004, 1, 1289-1295.

(30) Ali, M.; Shuaib, M.; Ansari, S. H. Phytochemistry 1997, 44, $1163-1168$.

(31) Siddiqui, B. S.; Arfeen, S.; Afshan, F.; Begum, S. Heterocycles 2005, 65, 857-863.

(32) Misico, R.; Veleiro, A. S.; Burton, G.; Oberti, J. C. Phytochemistry 1997, 45, 1045-1048.

(33) Shingu, K.; Furusawa, Y.; Nohara, T. Chem. Pharm. Bull. 1989, 37, 2132-2135.

(34) Zhu, X. H.; Ando, J.; Takagi, M.; Ikeda, T.; Nohara, T. Chem. Pharm. Bull. 2001, 49, 161-164.

(35) Misra, L.; Lal, P.; Sangwan, R. S.; Sangwan, N. S.; Uniyal, G. C.; Tuli, R. Phytochemistry 2005, 66, 2702-2707.

(36) Llanos, G. G.; Araujo, L. M.; Jiménez, I. A.; Moujir, L. M.; Vázquez, J. T.; Bazzocchi, I. L. Steroids 2010, 75, 974-978.

(37) Machin, R. P.; Veleiro, A. S.; Nicotra, V. E.; Oberti, J. C.; Padròn, J. M. J. Nat. Prod. 2010, 73, 966-968. 